\title{
RAMSES III: UN FARAÓN GUERRERO A FINALES DEL SEGUNDO MILENIO a. C.
}

\author{
POR
}

\author{
JESÚS TRELLO
}

\section{RESUMEN - ABSTRACT}

La irrupción en la historia de los llamados «pueblos del mar» alteró profundamente la evolución de las civilizaciones del mediterráneo oriental. Frente a ellos se alzó una figura individual, el faraón Ramses III, que detiene su estela devastadora ante las mismas puertas de Egipto. Pretendemos una visión actualizada de esta figura histórica, a la vista de las imágenes y los textos contemporáneos del rey.

The irruption in the history of the so called «Sea Peoples» profoundly altered the evolution of the Eastern Mediterranean civilizations. Pharaoh Ramses III was the individual figure who rose up to confront them and stopped their devastating path of destruction at the very border of Egypt. We shall try to give a current view of this historical figure, using the images and the contemporary texts related to this king.

\section{PALABRAS CLAVE - KEY WORDS}

Ramses III. Egipto. Edad Oscura. Guerras. Faraón.

Ramses III. Egypt. Dark Ages. Wars. Pharaoh.

\section{INTRODUCCIÓN}

El potente muro de contención que parece haber puesto freno al rodillo destructor de los llamados «pueblos del mar», fue la figura de un rey al que llamamos Ramses III (c. 11851153 a.C.), probablemente el último gran faraón de Egipto.

Sus títulos, como Rey del Alto y del Bajo Egipto User-Maat-Ra Mery-Amon (wsr-m3 ${ }^{c} t-r^{c}$ mry-imn) y como Hijo de Ra, Ra-Mes-su Heqa-Iunu ( $\mathrm{r}^{\mathrm{c}}-\mathrm{ms}-\mathrm{s}(\mathrm{w})$ ḥk3-iwnw), son una síntesis de las dos grandes corrientes religiosas del Imperio Nuevo, que parecen haber superado, en este momento histórico, los fuertes antagonismos que habían provocado graves desórdenes internos.

Sin embargo en los relieves y representaciones de los grandes edificios tebanos hay abundantes escenas de guerra. Pero el enemigo, en esta ocasión es extranjero. Ramses III aparece ante nosotros como un gran guerrero, defensor de los valores egipcios frente a los enemigos extranjeros.

Ramses III no nació príncipe de Egipto, sino hijo de un jefe militar, Sethnajt, que había alcanzado el poder al final de la agonizante dinastía XIX, fundando una nueva dinastía. Su educación se debió desarrollar, por tanto, en un ambiente castrense. 


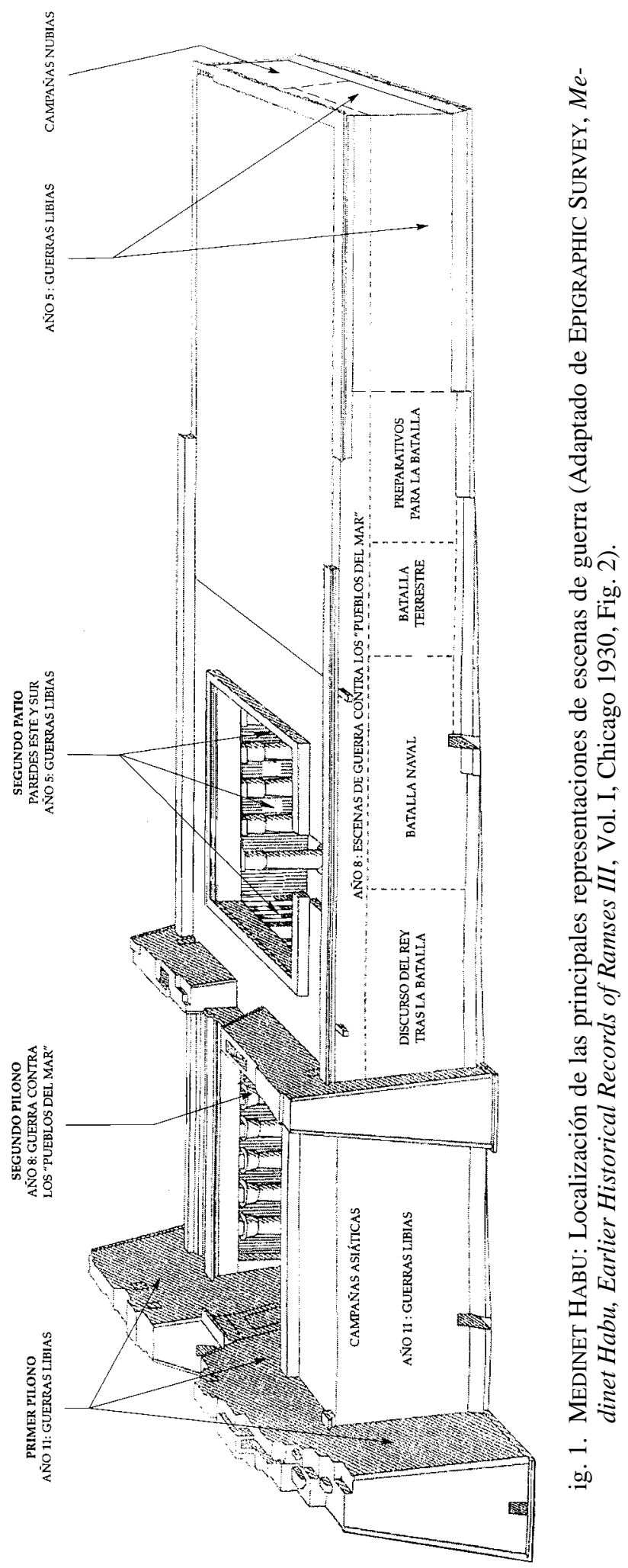


Además luchó junto a su padre en el proceso de afianzamiento del nuevo poder encarnado por Sethnajt. El propio nombre de su padre es un teóforo de Seth, lo que índica hasta que punto este dios guerrero está presente en el comienzo de la dinastía, al igual que ocurrió en el comienzo de la anterior.

En la capital, Pi-Ramses fue encontrada una estela ${ }^{1}$ donde, precisamente este dios guerrero Ba'al-Seth entrega a Ramses III la espada jepesh (hpš), en un gesto típico de incitación y aprobación divina al ejercicio de la actividad militar.

Luchó contra los enemigos tradicionales del país, los habitantes del desiertos oriental y del occidental, y contra los vecinos africanos del sur. Además tuvo que luchar contra un peligro nuevo del que existían muy pocas referencias previas en los anales egipcios: la invasión de los que se ha dado en llamar «pueblos del mar». Este último evento es el resultado final de un complejo fenómeno que solo es posible entender en un contexto geográfico mucho más amplio que el de los vecinos de Egipto, y unas circunstancias históricas que desbordan el reinado de Ramses III.

Es difícil conocer cual fue exactamente la participación de Ramses III en las batallas en las que aparece representado. ¿Acostumbraba a entrar con su carro y a galope tendido en medio de las batallas? En el esquema que se repite en las diferentes escenas vemos al rey lanzar el grito de guerra y cargar contra el enemigo a la cabeza de sus tropas. ¿Ocurría realmente así?. No lo sabemos con seguridad. Pero es más que probable que estuviera presente en el teatro de operaciones. Los faraones egipcios parece que acostumbraban a hacerlo, y esto costó la vida a varios monarcas egipcios; el caso más conocido es el de Séqénenré Taa ${ }^{2}$. Podremos matizar las circunstancias e intervinientes en la batalla contra los «pueblos del mar», pero no dudamos que el ejército de Ramses III tuvo que luchar contra estos pueblos, porque lo confirman terceras fuentes. En esta guerra no parece que se dieran situaciones paralelas. Los artesanos de Ramses III, en este caso, probablemente no encontraron modelos que repetir ${ }^{3}$ para representar las luchas contra los «pueblos del mar» ${ }^{4}$.

Aunque el esquema narrativo que se emplea en los relieves y los textos de la época es el mismo que encontramos al comienzo del Imperio Nuevo, se está aplicando a una realidad histórica completamente diferente, lo cual podemos percibir rápidamente en la termilogía ${ }^{5}$ utilizada. Hay una gran diferencia entre la situación de expansión imperialista de Thutmose III, y la dura defensa de las fronteras naturales de Egipto que tiene que realizar Ramses III.

1 Actualmente en el Museo Egipcio del Cairo, J.E. 88879. Ver I. CORNELIUS The Iconography of the Canaanita Gods Reshef and Ba`al, Göttingen, 1994, p. 145.

2 Ver C. VANDERSLEYen, L'Égypte et la Vallée du Nil. Tome II: De la fin de l'Ancien Empire à la fin du Nouvel Empire, Paris 1995, p. 189. Tanto para la datación de los reinados como para los aspectos históricos más significativos hemos seguido las tesis de este autor.

3 Al menos, hasta ahora, no han sido encontrados.

${ }^{4}$ El afán por negar la historicidad de las guerras de Ramses III, ha llevado a algunos autores a plantear que los relieves de Medinet Habu con escenas de las guerras contra los «Pueblos del Mar», de las cuales no existen antecedentes, habrían sido copiadas del inmediato templo mortuorio de Merneptah (totalmente destruido hoy y, por tanto, resulta muy difícil de verificar la tesis), y que el Papiro Harris I, en su sección histórica, habría sido inspirado en los relieves de Medinet Habu. Ver Leonard H. LESKO «The Wars of Ramses III», Serapis 6, (1981/82) p. 86. En realidad el esquema narrativo de este tipo de acontecimientos es practicamente el mismo desde la dinastía XII, hallando sus exponentes más significativos entre las dinastías XVIII y el período ramésida. Ver B. CIFOLA «Ramses III and the Sea Peoples. A Structural Analisys of the Medinet Habu Inscriptions», Orientalia 57, 1988, p. 301, quien basa su metodología en el modelo de V.J. Propp (Morfologija skazki, Leningrad 1928). En nuestra opinión, es muy probable que una parte significativa de los relieves ramésidas de esta época y posteriores hayan tenido como modelos representaciones anteriores, pero ello no nos permite negar toda posibilidad histórica de sus informaciones aunque, evidentemente, obliga a matizarlas. Creemos que sí pudieron ser «históricas» desde la perspectiva de los egipcios contemporáneos del faraón reinante.

5 Ver B. CIFOLA «The Terminology of Ramses III's Historical Records With a Formal Analysis of the War Scenes», Orientalia 60, 1991, pp. 9-57. 

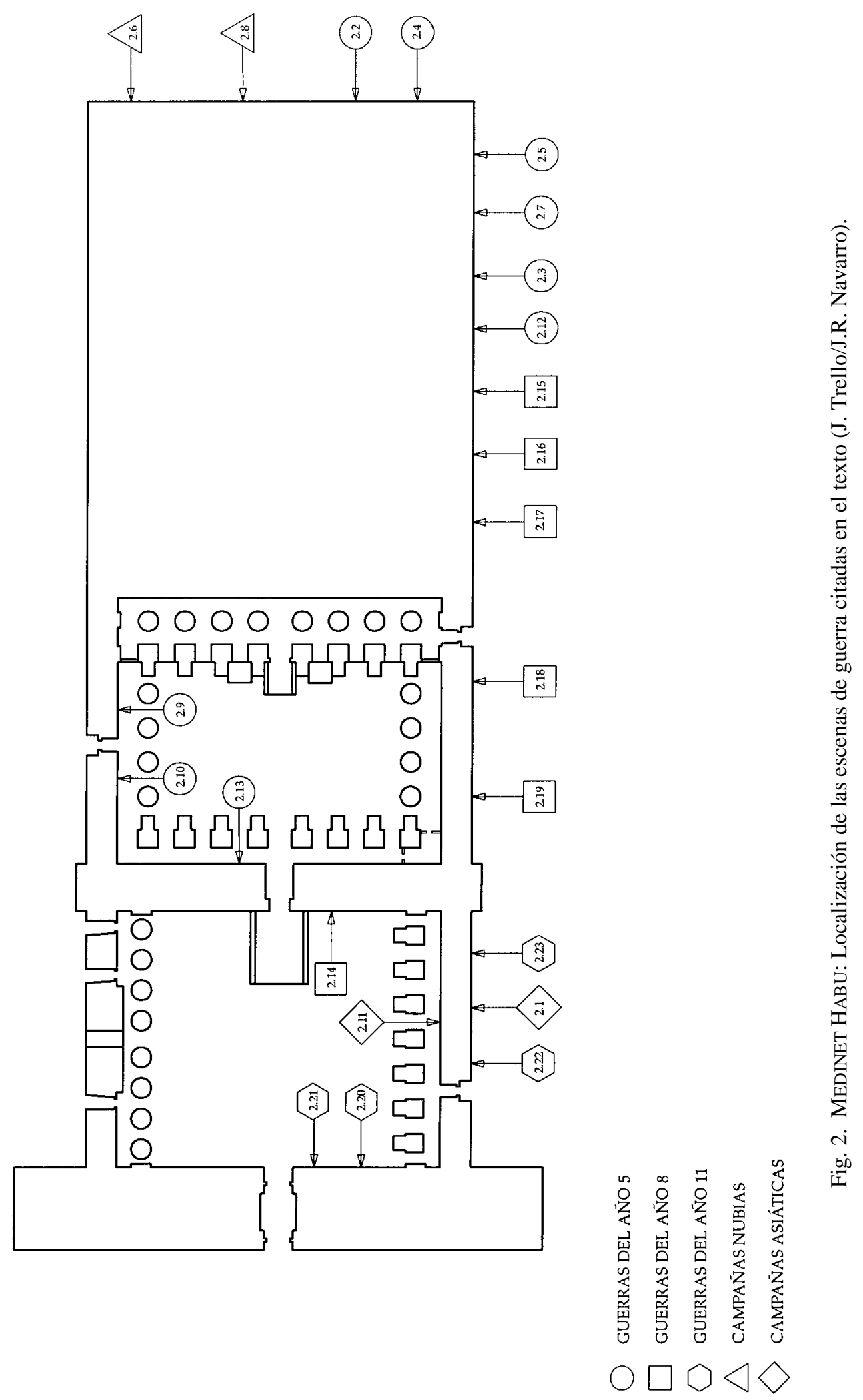
Los hijos de Ramses III parece que también lucharon junto a su padre al igual que este faraón lo hiciera junto al suyo. De hecho los hijos del rey formaban parte de la cúspide militar en campaña. Así, vemos al rey dirigirse a su hijo para darle instrucciones tras la toma de una ciudad :6 "... The King himself says to the Crown Prince, Royal Scribe, Chief Commander of the Army, and Royal Son, ...».

El ejército generalmente, cuando estaba en campaña, se componía de un primer contingente de entre una y cuatro divisiones de unos 5.000 hombres cada una. En total, aproximadamente 20.000 hombres, como máximo. Cada división disponía de soldados de infantería y soldados de carros. Cada una de las divisiones estaba bajo la advocación de uno de los grandes dioses de Egipto (las divisiones de Amón, Ra, Ptah y Sutej) ${ }^{7}$, y cada división era un grupo completo y listo para desarrollar sus funciones con total autonomía. En combate, al frente de cada división se situaba, al menos nominalmente, un príncipe o el mismo rey. Además, cuando estaban en campaña contaban con otras tropas secundarias que reforzaban su acción contra el enemigo o reponían bajas en combate.

Al frente de cada división estaba habitualmente un jefe ${ }^{8}$ quién, a su vez, tenía bajo sus órdenes a 20 mandos que dirigían cada uno 250 hombres $^{9}$. El oficial de menor rango mandaba 50 hombres y era llamado «el más grande de los cincuenta». Fue en organizar este nivel del ejército donde tanto Sethnajt como Ramses III se emplearon más a fondo pues, como soldados profesionales que eran, sabían que la eficacia final del conjunto, dependía de la eficacia de sus unidades más pequeñas, algo que no resultaba tan familiar a los últimos reyes de la dinastía precedente, todos ellos cortesanos más hábiles y preocupados por sus intrigas palaciegas que por defender a Egipto de los peligros evidentes que se cernían sobre sus fronteras.

El ejército egipcio disponía de dos «armas»; la infantería y los carros, que en época ramésida estaban separadas.

No es casual que el principal cuerpo estuviera constituido por el arma de carros ${ }^{10}$ de guerra, puesto que estaba perfectamente adaptada para el combate en el Delta Oriental, en amplias zonas de Canaán y en la zona norte del Delta Occidental, principales escenarios de lucha de toda posible invasión en ese momento histórico. Cada carro de guerra llevaba una dotación de dos hombres: un conductor ${ }^{11} \mathrm{y}$ un soldado combatiente. Las funciones de conductor y las de combatiente ${ }^{12}$ parecer ser intercambiables durante el combate. Ambos deben, según las circunstancias, asegurar las funciones básicas en la batalla: conducir el carro, combatir y proteger al equipo con un escudo. El ejército de carros estaba dividido en «escuadrones» de 25 carros y cada «escuadrón» era mandado por un «Carrista de la Residencia».

6 Ver fig. 2.1. Textos en W.F. EDGERTON y J. A. WILSON, Historical Records of Ramses III. The Texts in Medinet Habu. Volumes I and II, Chicago 1936, p. 97. La imagen puede consultarse en EPIGRAPHIC SURVEY, Medinet Habu, Volume II, Later Historical Records of Ramses III, Chicago 1932, plate 91 Ver también J. H. BREASTED, Ancient Records of Egypt, Volume IV, New York 1962 (1906), \# 121, p. 71. Tengo que agradecer a D. José Ramòn Navarro González la ayuda prestada para realizar las Figuras 1 y 2. Ello ha permitido ubicar con claridad los textos e imágenes citadas en este trabajo.

7 Ver en la batalla de Kadesh, las divisiones de Amón, Ra, Ptah y Sutej. Kenneth A. Kitchen, Ramesside Inscriptions, Historical and Biographical, Oxford 1983. Vol. II, 23, 11, Párrafos 61-63.

8 Un uartu. Ver R.O. FAULKNER «Egyptian Military Organization» J.E.A. 39, London 1953, pp. 32-47.

9 Ver R.O. FAULKNER «Egyptian Military Organization» J.E.A. 39, London 1953, p. 45.

10 Con Thutmose III el ejército egipcio en campaña contaba con dos divisiones, estando los carros integrados en cada una de ellas. El ejército de carros, como un arma separada de la infantería, aparece documentado por primera vez en el período amárnico. Suponemos por tanto que es en este período cuando se produce una reorganización del ejército que apuesta decididamente por el arma de carros, motivada por la situación en la zona sirio-palestina. Ver A. R SCHULMAN Military Rank, Title, and Organization in the Egyptian New Kingdom Berlín, 1964, P. 79.

${ }^{11}$ Esta era una habilidad en la que se adiestraba prioritariamente a los hijos del rey. En Medinet Habu encontramos retratado a $P 3-R^{c}-\underline{h r}$-wnmy.f, un príncipe hijo de Ramses III que se dice es $k \underline{d} n$, así como en su tumba, la QV 42 , donde se dice que es $k \underline{d} n$ de la «Gran Cuadra de Ramses III en la residencia del Rey» Ver J. YOYOTTE y J. LOPEZ «L'Organisation de 1’Armee au Nouvel Empire Egyptien» en Bibliotheca Orientalis XXVI n 1-2 Januari-Maart 1969, p. 18.

${ }^{12}$ Los títulos de $k \underline{d} n$ (conductor) y $k r^{`} W$ (combatiente) parecen estar referidos a su posición en los desfiles o paradas militares. Las agrupaciones de carros estaban capitaneadas por los hrry $k r^{`} W$. Ver J. YOYOTTE y J. LOPEZ «L'Organisation de l’Armee au Nouvel Empire Egyptien» en Bibliotheca Orientalis XXVI no 1-2 Januari-Maart 1969, p. 11. 


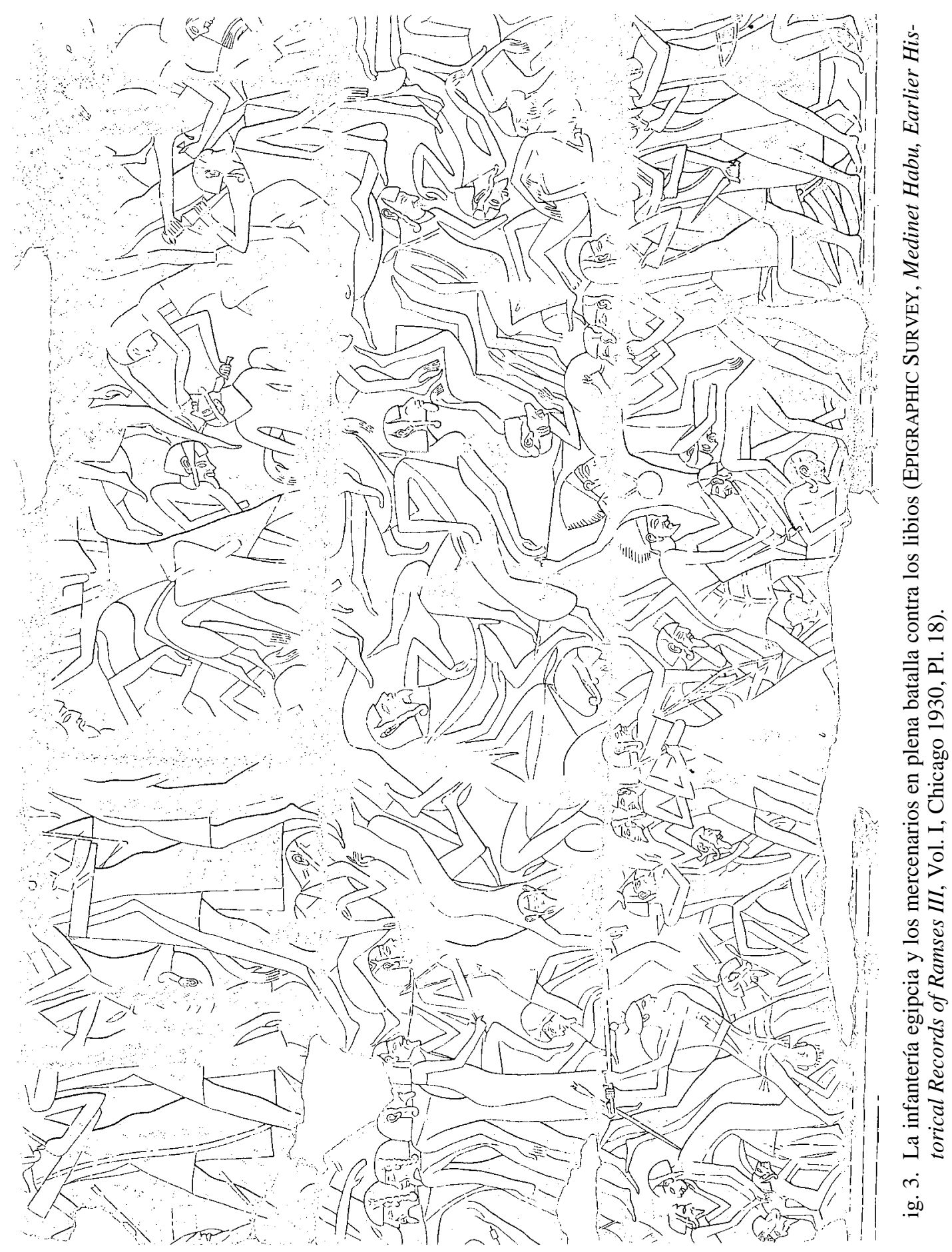




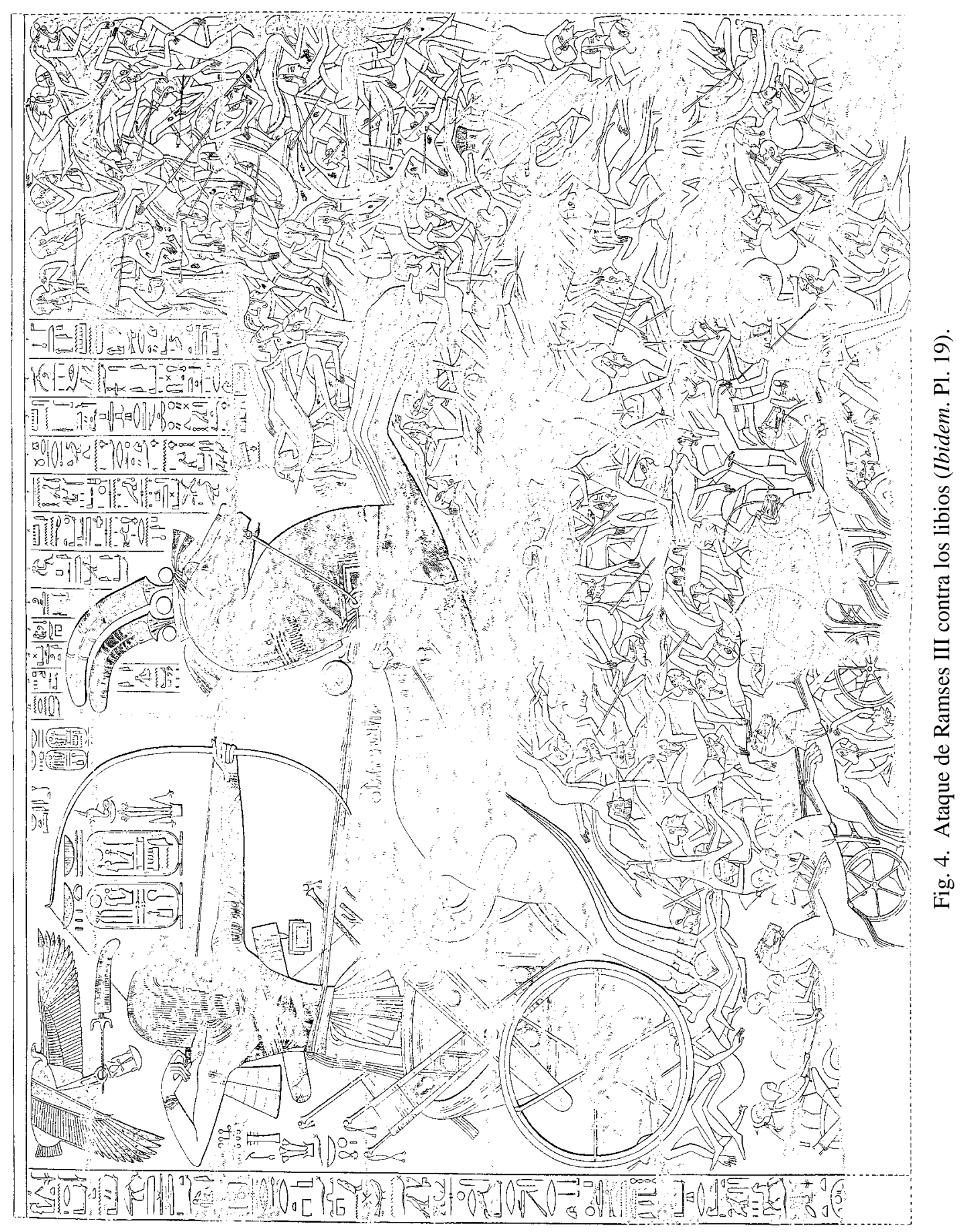


El carro de guerra egipcio tenía dos ruedas y disponía de una sencilla plataforma, muy ligera. Estaba tirado por dos caballos.

Los caballos del rey eran cuidados especialmente y conocemos el nombre de los equipos que el rey utilizó en las batallas. Por ejemplo sobre los caballos que Ramses III utiliza en la batalla de la segunda guerra líbica aparece la inscripción: «The great chief span of his majesty, «Beloved of Amon», of the great stable of Usermare-Meriamon, of the Court»13. En los caballos que utiliza durante la toma de dos ciudades hititas, son denominados: «The great chief span [of] his majesty, "[Vic «]tory in Tebes» ${ }^{14}$. En otras situaciones utiliza diferentes tiros de caballos que iremos viendo al tratar las diferentes acciones militares ${ }^{15}$.

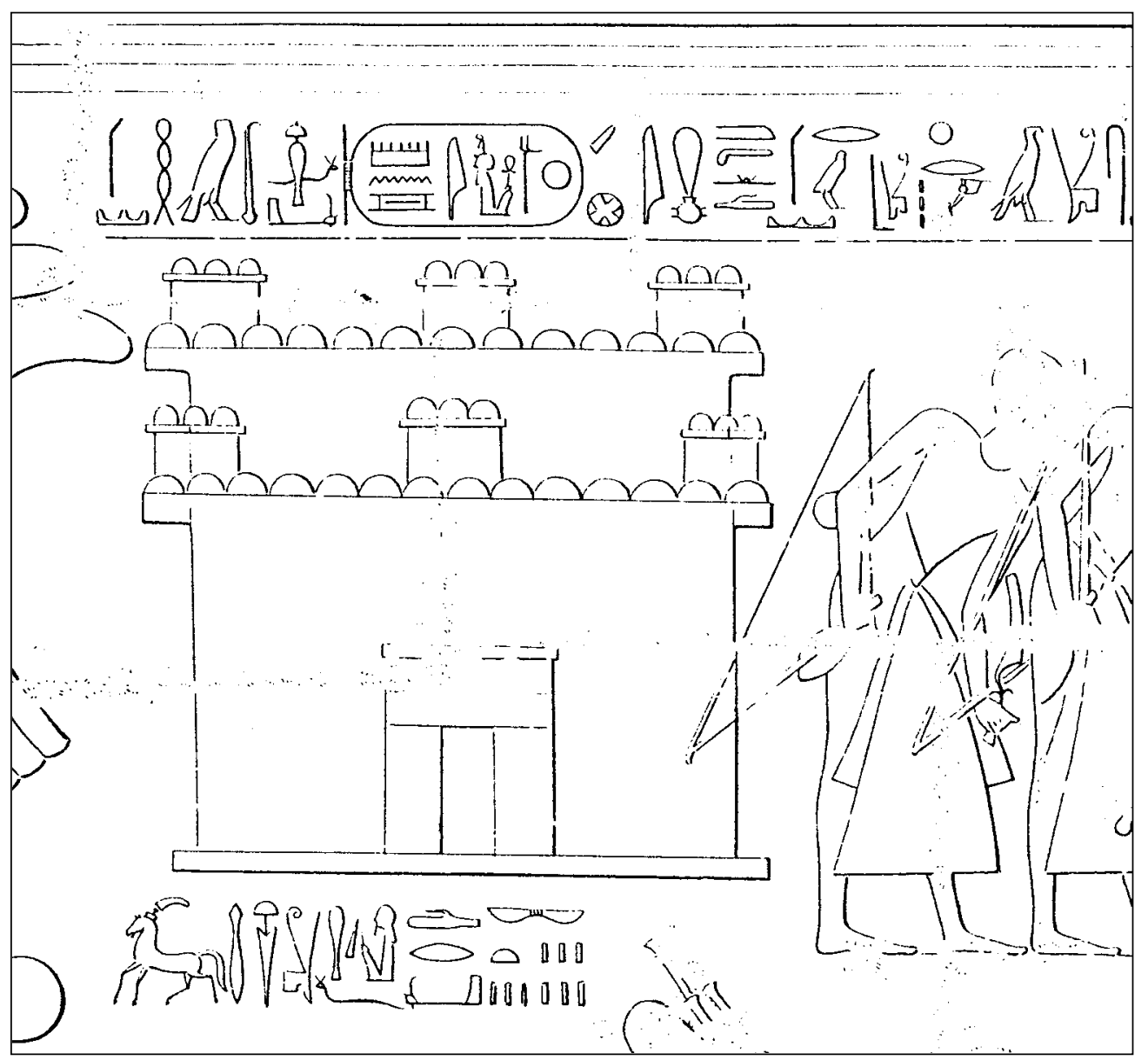

Fig. 5. Fortaleza junto a la cual Ramses III hace balance de la batalla contra los libios (Ibidem. Pl. 22a).

13 Ver fig. 2.2. W.F. Edgerton y J. A. WiLSON, Historical Records of Ramses III. The Texts in Medinet Habu. Volumes I and II, Chicago 1936, p. 9. La imagen puede consultarse en EPIGRAPHIC SURVEY, Medinet Habu, Volume I, Earlier Historical Records of Ramses III, Chicago 1930, plate 16. Ver también J. H. BREASTED, Ancient Records of Egypt, Volume IV, New York 1962 (1906), \# 106, p. 63.

14 Ver fig. 2.3. W.F. Edgerton y J. A. WILSON, Historical Records of Ramses III. The Texts in Medinet Habu. Volumes I and II, Chicago 1936, p. 12. La imagen puede consultarse en EPIGRAPHIC SURVEY, Medinet Habu, Volume I, Earlier Historical Records of Ramses III, Chicago 1930, plate 19. Ver también J. H. BREASTED, Ancient Records of Egypt, Volume IV, New York 1962 (1906), \# 120, p. 70.

15 Ver J. H. BREASTED, Ancient Records of Egypt, Volume IV, New York 1962 (1906), \# 123, p. 72. 
La infantería estaba compuesta principalmente por dos tipos de soldados; los veteranos y los más jóvenes ${ }^{16}$. Los soldados de infantería eran reclutados por el «escriba de reclutas» ${ }^{17}$. Ramses III dispuso para el ejército, de uno de cada diez hombres por circunscripción, excluido el personal al servicio de los templos, que estaban exentos de este servicio militar.

El contingente ${ }^{18}$ de tropas de un barco era reclutado como los soldados de tierra y sometidos a un adiestramiento especial, antes de pasar a lo que podríamos denominar «infantería de marina».

Los egipcios siempre utilizaron tropas extranjeras en su ejército; generalmente como armas especializadas. Un profesional de la guerra, como era Ramses III, las utilizó sistemáticamente.

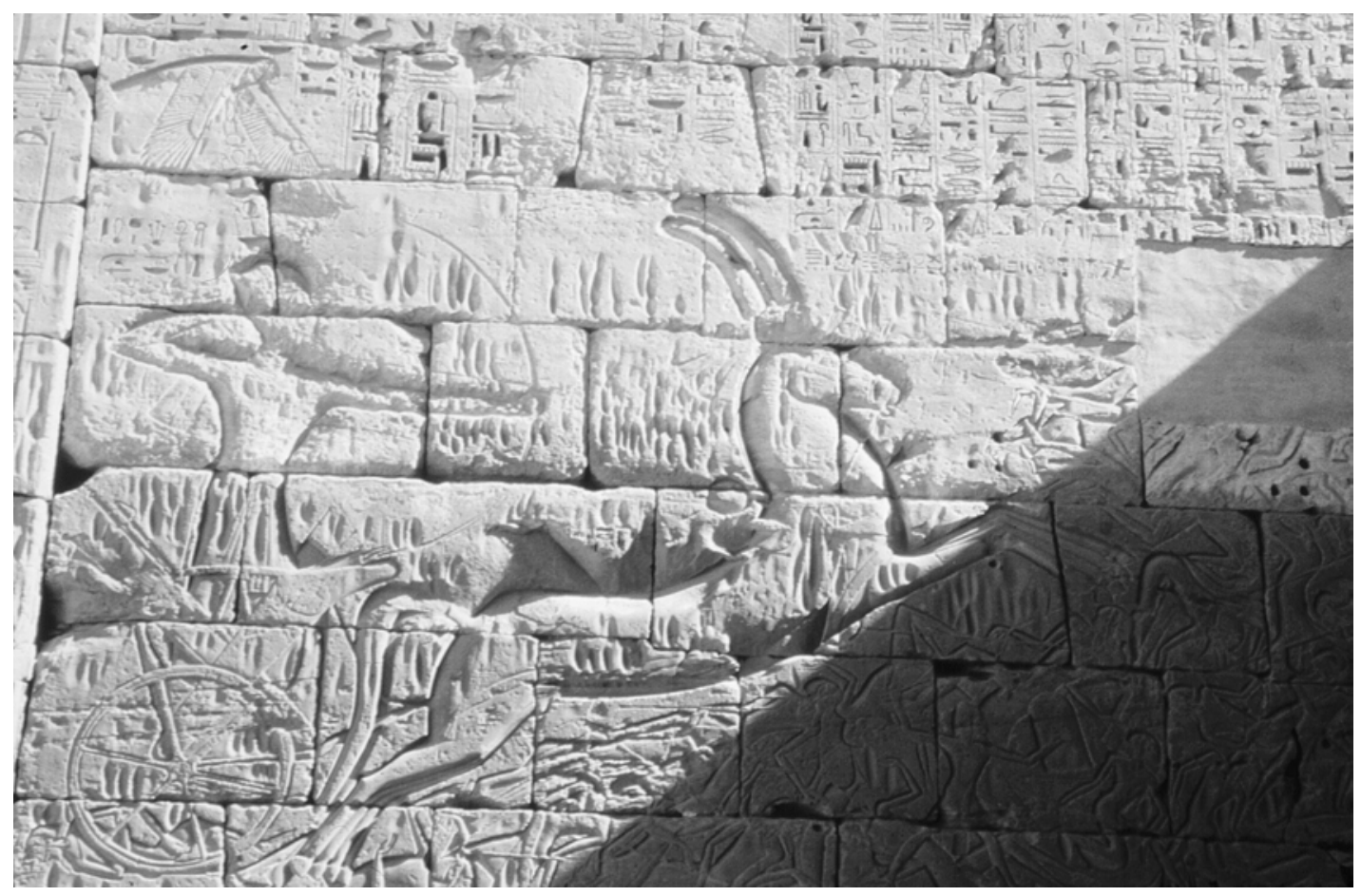

Fíg. 6. El rey Ramses III en su carro de guerra atacando a los libios (Foto: J. Trello).

Parece que las tropas extranjeras tienen su origen en los prisioneros de guerra. Tras su sometimiento y adscripción a la nueva función pasaban a depender del presupuesto estatal que era gestionado por la compleja administración faraónica.

16 Los veteranos, llamados mnf3t o mnfyt y los más jóvenes llamados ḥwnw nfrw. Los cuerpos de élite que formaban la punta de lanza en un ataque eran, en opinión de Faulkner (op. cit. 45-47), denominados knyt nsw, es decir los «valientes del rey». En opinión de Schulman no hay evidencias suficientes que constaten la existencia de un cuerpo especial del ejército que corresponda a «tropas de choque» con ese nombre. Ver A. R. SchULman Military Rank, Title, and Organization in the Egyptian New Kingdom Berlín, 1964, p. 67.

${ }_{17}$ Llamado $s \check{s}$ nfr $w$.

18 El contingente de tropas de un barco era denominado hnyt. Ver A. R. SCHULMAN Military Rank, Title, and Organization in the Egyptian New Kingdom Berlín, 1964, pp. 19-20. 
En los desfiles del ejército de Ramses III se pueden ver unidades de soldados compuestas por gentes del desierto oriental. Los arqueros nubios forman parte del ejército egipcio en todas las épocas. Las gentes del desierto occidental fueron empleadas básicamente en labores de policía tanto en las fortalezas de la frontera como en las propias ciudades.

En cuanto a los pueblos del norte, podemos ver a un cuerpo de soldados peleset $^{19}$ en las guerras contra los pueblos del sur. Pero son los shardana, los soldados extranjeros que tienen una presencia relevante y permanente en el ejército de Ramses III.

\section{LAS GUERRAS DE RAMSES III}

Tenemos $^{20}$ datadas las guerras contra los pueblos del oeste y las guerras contra los pueblos del norte. Las guerras sirias y contra los pueblos del sur no las tenemos bien datadas y son cuestionadas por algunos autores.

Las guerras contra los pueblos del oeste, llamadas habitualmente las «guerras libias» tienen sus episodios más transcendentales en los años 5 y 11.

\subsection{Guerras del año 5 contra los pueblos del desierto occidental.}

Las tribus del desierto occidental eran una amenaza permanente para los habitantes de las orillas del Nilo. Ramses II construyó una red de fuertes para proteger el Delta. Uno de los fuertes que mejor conocemos es la fortaleza de Tchemeh ${ }^{21}$. En realidad esta gran fortaleza, el mayor asentamiento comercial y militar creado por Ramses II en la costa oeste es, en esencia, un pozo de agua protegido. Con ello controlaban los posibles movimientos masivos de

19 Estos soldados suelen llevar un tocado, frecuentemente identificado como «corona de plumas», y que más bien parece responder a un adorno formado con crines de caballo sobre un casco muy ligero, posiblemente de piel, que en su conjunto podría hacer parecer al soldado más alto y de aspecto más feroz. Estos tocados de crines de caballos son fácilmente observables en los cascos de los soldados hoplitas griegos, muy posteriores. No obstante sus antecedentes más inmediatos podrían estar en los llamados ahhiyawa en las fuentes hititas, identificables quizás con los aqueos o micénicos. Ver M. BENDALA»Los albores de Grecia» Historias del Viejo Mundo. Historia $16 n^{\circ} 9$, p. 106, y más extensamente en S. Gitin, A. MAZAR y E. STERn (ed.) Mediterranean Peoples in transition. Thirteenth to Early Centuries BCE, Jerusalem 1998

20 Prácticamente todas las situaciones que describimos como «guerras de Ramses III» tienen la misma estructura narrativa: $1^{\circ}$ Aparición de una situación de desorden; $2^{\circ}$ Intervención del rey restaurando el orden; $3^{\circ}$ Descripción de la situación normalizada. A su vez, la organización interna del texto suele contener los siguientes elementos: 1. Fecha; 2. Titulatura real; 3. Introducción retórica; 4. Narración; 5. Conclusión retórica. El punto «4. Narración», suele contener los siguientes temas: 1. Precedentes en Egipto; 2. Acerca del enemigo; 3. La acción del enemigo; 4. La movilización del ejército egipcio; 5. La acción del rey; 6. El desgraciado final del enemigo; 7. La excelente situación en la que queda Egipto. Las diferencias de estructura de las distintas guerras en relación con la estructura normalizada, nos permite aproximarnos a las singularidades de los acontecimientos concretos. Ver B. CIFOLA «Ramses III and the Sea Peoples. A Structural Analisys of the Medinet Habu Inscriptions», Orientalia 57, 1988, p. 275-306.

${ }^{21} \mathrm{El}$ lugar, situado en la costa mediterránea, a unos $300 \mathrm{Km}$. al oeste de Alejandría, se llama actualmente Zawiyet Umm el-Rajam, y está muy próximo a Mersa Matrouh. Fue excavado por Alan Rowe y por Labib Habachi. Desde 1994 trabaja en este yacimiento un equipo de la Universidad de Liverpool. Ver Ramesses II's Forgotten Frontier. Egyptian Archaelogy 11. The Bulletin of the Egypt Exploration Society (1997). pp. 23-24. La fortaleza fue ocupada por los pueblos del desierto occidental inmeditamente después de ser abandonada por los egipcios. Ver F. SIMPSON, «Evidence for Late Bronze Age Libyan Culture in the Western Desert» en Proceedings of the Eighth International Congress of Egyptologists, Cairo 28 marzo-3 abril 2000, (e.p.). Esta fortaleza era defendida por una guarnición militar, al frente de la cual Ramses II puso a un comandante, Neb-Re, cuya efigie quedó en la fortaleza, grabada en la piedra para la eternidad, adorando el nombre de su rey. Neb-Re posiblemente gozaba de un alto grado de autonomía en su ámbito de actuación. Ver S. SNAPE «Apocalypse Then? Neb-Re and his Fortress at Zawiyet Umm el-Rakham» en Proceedings of the Eighth International Congress of Egyptologists, Cairo 28 marzo-3 abril 2000, (e.p.). 
población hacia los pastos del Delta o, sencillamente, regulaban el comercio internacional a través de este punto fronterizo.

La situación de inestabilidad y descomposición política de los últimos reinados de la dinastía XIX había dado lugar a una ocupación no deseada del Delta por los pueblos del desierto occidental. Situación semejante a la que había provocado la guerra de Merenptah contra estos pueblos.

Esta ocupación parece haber alcanzado ambas orillas del brazo canópico del Nilo, en esa época llamado el «Gran Río», desde Menfis hasta Qerben (un lugar probablemente muy próximo a Canopo) $)^{22}$.

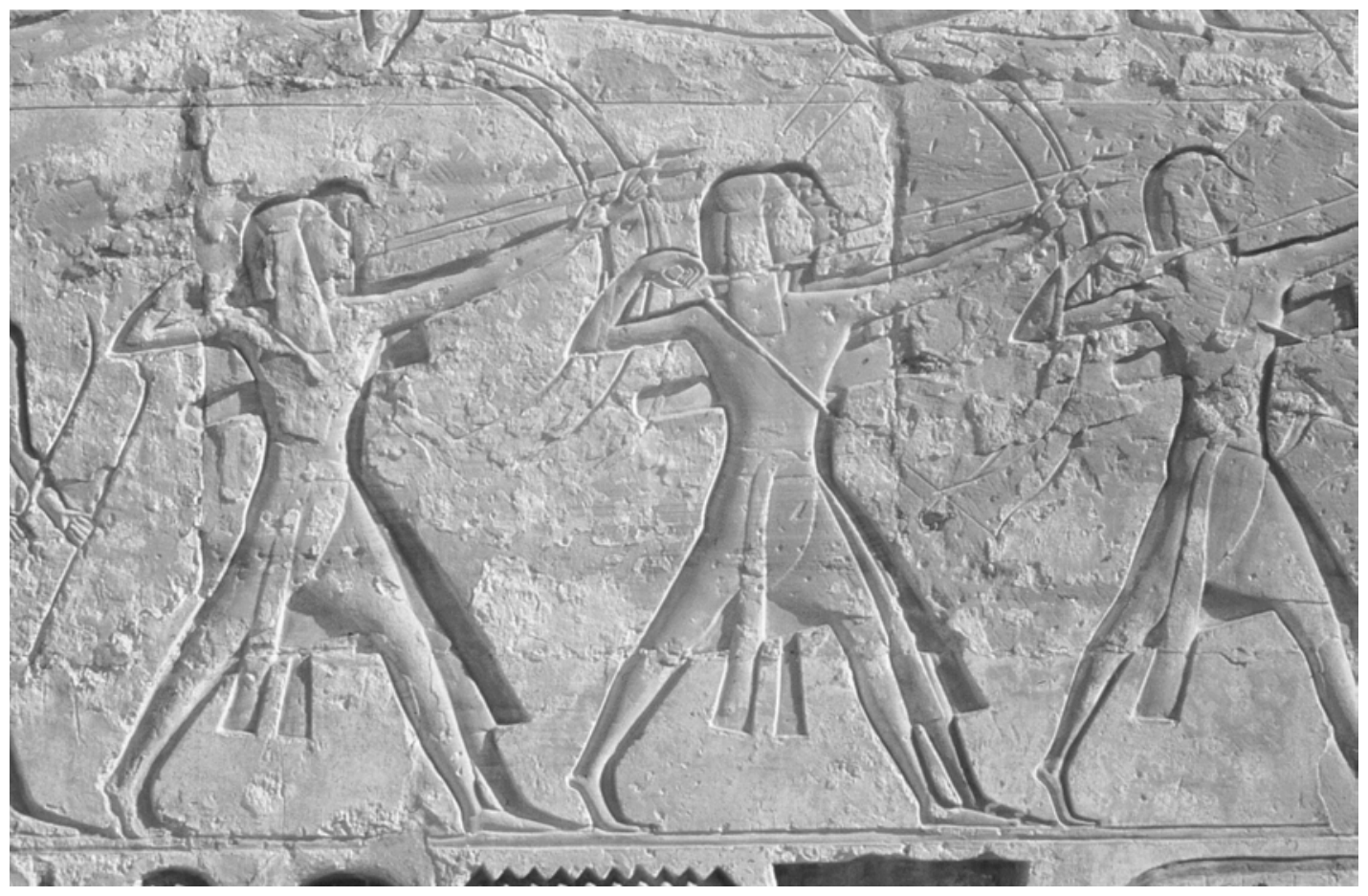

Fig. 7. Príncipes de Egipto disparando con arco (Foto: J. Trello).

Las fortalezas que en su día ubicara Ramses II en Marmárica, ya estaban en desuso en tiempos de Merenptah, posiblemente porque ya habían sido rebasadas ampliamente por la invasión de los enemigos confederados del desierto occidental ${ }^{23}$.

En el año 5 de Ramses III tuvo lugar una guerra contra los Pueblos del Oeste. (Fig. 8) No conocemos con exactitud el lugar donde se produjo el enfrentamiento, pero no tenemos constancia de que las luchas se librasen en el Delta; al menos ninguna fuente nos lo cita. Sí parece que amenazaban las ciudades del vértice sur del Delta, por lo que nos atrevemos a lanzar la hipótesis de que el grueso del ejército, destacado en el noreste del Delta, abandonara sus acuartelamientos, protegido con su cuerpo de elite, los carros, y atacara al enemigo en algún lugar al sur de Menfis.

22 Ver J. H. BREASTED, Ancient Records of Egypt, Volume IV, New York 1962 (1906), \# 35, p. 18.

23 Ver K.A. KitCHEN, The arrival of the libyans in Late New Kingdom Egypt, A. LEAHY (Ed.) Libya and Egypt c. 1305-1750 B.C., London 1990, p. 19. 
La batalla que siguió fue el primer éxito militar de envergadura durante el reinado de Ramses III. Fue una enfrentamiento en el que los ejércitos de libios y egipcios se enfrentaron encarnizadamente «en una sola vez».

Recordemos lo que nos dice el Papiro Harris I:

Les Libou et les Me-(77,1)-shwesh (s')étaient installés en Kémet, s'étant emparés des cités de la Bordure-occidentale (du Delta), depuis Houtkaptah jusqu’à Qerben ${ }^{924}$,(puis) ayant atteint le Grand-Fleuve sur toute (la longueur de) sa rive $(77,2)$. Et ce sont eux qui ont dépouillé les cités du nome de Xoïs pendant de nombreuses et innombrables années, tandis qu'ils étaient en Kémet ${ }^{925}$. (Or), voyez, je les ai réduits en poussière ${ }^{h}$, (ils ont été) détruits en une (seule) fois ${ }^{24}$.

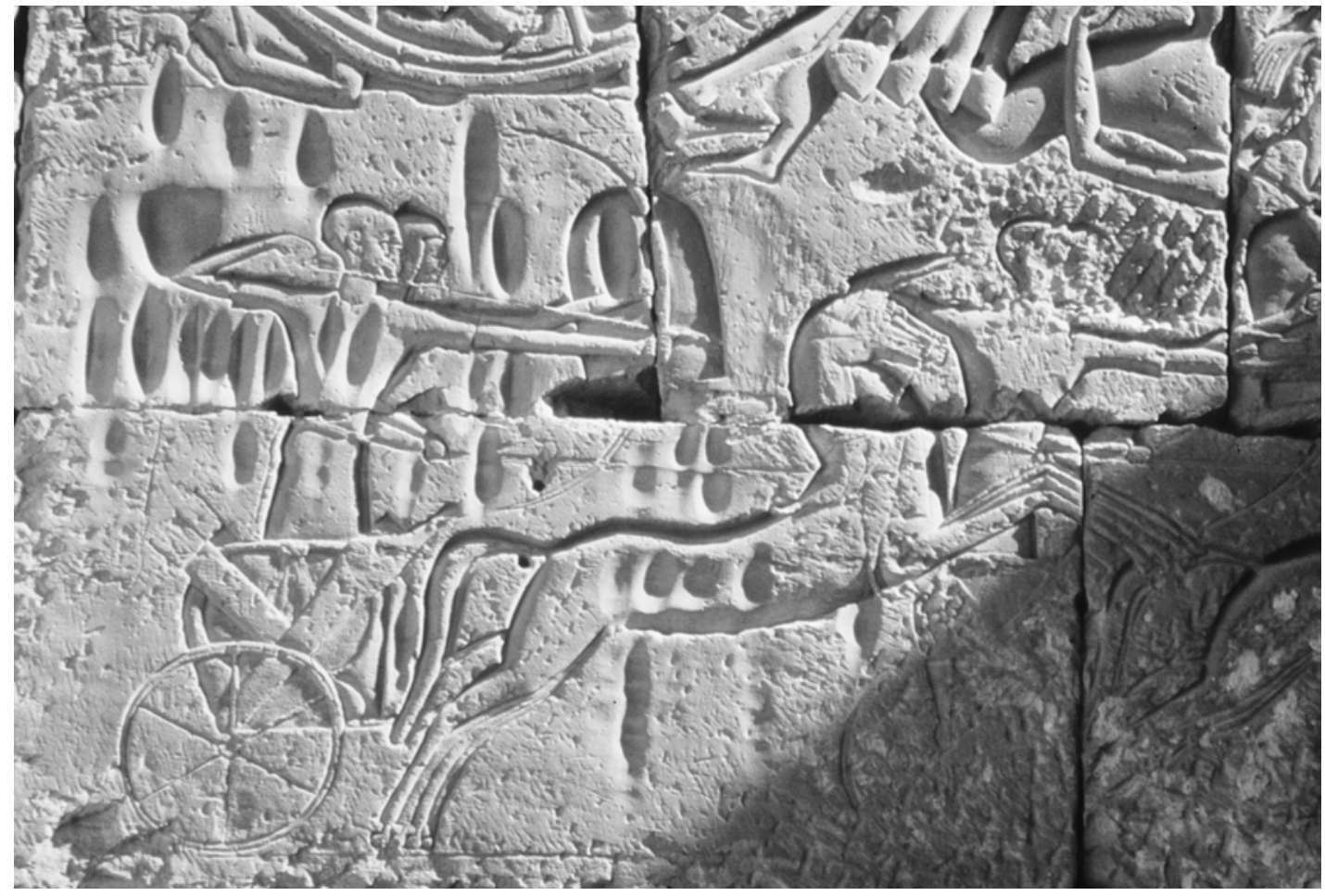

Fig. 8. Carro de guerra egipcio en batalla (Foto: J. Trello).

24 Ver P. GRANDET, Le Papyrus Harris I (BM 9999), Volume I, Le Caire 1994, p. 337. En esta traducción hay que señalar la opinión discrepante de Claude Vandersleyen «Une des idées fixes dont il faut débarrasser l'égyptologie, c'est 1'idée que les "Libyens“"sont un peuple qui vivait au nord-ouest de 1’Egypte, contre la frontiére ouest du Delta.» En su opinión, este ha sido un error que ha llevado a realizar traducciones equivocadas y a interpretaciones inadecuadas acerca de los acontecimientos que se produjeron y el lugar de los mismos, en las guerras con estos pueblos. Vandersleyen expuso sus ideas en una brillante ponencia bajo el título Les guerres de Mérenptah et de Ramsés III contre les peuples de l'Ouest, et leurs rapports avec le Delta, presentada en el Seventh International Congress of Egyptologists, celebrado en Cambridge, del 3 al 9 de septiembre de 1995, y al que tuvimos oportunidad de asistir. Aquí seguiremos sus tesis, que ubican el lugar de origen de los libu y los mesehuesh en el desierto occidental de Egipto, a la altura de Nubia/Sudán. Respetamos la traducción de Grandet, que en este punto no coincide con la de Vandersleyen, por coherencia en los textos. 
Pero ¿de donde procedían las tribus que constituían tan terrible amenaza para los egipcios? Los libu y los mashauesh eran dos tribus pertenecientes al pueblo tchemehu (tmhu), vivían en el desierto occidental, muy al sur, a la altura de Nubia y Sudán, más al oeste de las tierras ocupadas por los tchehenu $(t h n w)$. Este último pueblo vivía en contacto con los egipcios, en la frontera occidental, y habitualmente no parecía causar demasiados problemas.

«Then one came to say to his majesty: «The Tehenu [are in motion]; they are making [a conspiracy]. They are gathered and assembled without number, consisting of Rebu, Seped, and Meshwesh, lands assembled to [advance] themselves, to [aggrandize] themselves against Egypt». His majesty arrived at the horizon of the All-Lord to pray for victory and a mighty sword from his father Amon, Lord of the Gods. He commissions.

Him in strength, and his hand is with him to destroy the land of Temeh, which has transgressed his frontier. Montu and Set are his magical protection on his right hand and his left hand; Upwawet is in front of him, penetrating the roads. They cause his might to be strong and his heart to be stout, [in order to] cast down the boastful lands» ${ }^{25}$.

Así pues, Ramses III tuvo que enfrentarse a un grupo de pueblos organizados y dirigidos por el jefe de los libu, Themer, quien además contaba con el apoyo de los thekel y de los peleset los cuales habrían enviado algunos barcos en su ayuda ${ }^{26}$. Por otra parte, también el ejército egipcio había utilizado entre sus tropas a soldados mercenarios peleset, que aparecen más tarde capitaneando a los «Pueblos del Mar» ${ }^{27}$, contra los que habría de enfrentarse Ramses III.

Faraón reunió sus tropas y puso en marcha el ejército egipcio. Delante va el estandarte de Amón, rey de los dioses, el cual manifiesta: «...Words spoken by Amon-Re, King of the Gods: "Behold, I am in front of thee, my son, Lord of the Two Lands: Usermare-Meriamon. I set thy fame throughout the Nine Bows, the awe of thee in the hearts of their chiefs. I open for thee the ways of the land of Temeh; I tread them before thy horses» ${ }^{28}$.

Previamente Ramses III había obtenido del dios Amón una especie de legitimación para la acción bélica que iba a emprender.

Los dos ejércitos se prepararon para el gran enfrentamiento: "The land of Temeh was come, gathered together in one place, consisting of Rebu, Seped, and Meshwesh, - - - - _ 29.

La carga del rey contra los libios (Fig. 9) causó estragos en las filas enemigas: «...Live the good god, Montu when he goes forth, beautiful at horsemanship, charging into hundredthousands, mighty of arm, stretching out the arm and sending his arrow to the spot which he may have desired; a bull fighting - - -, steadfast of heart upon the field [of battle] - - -, sharp of horns, to overthrow [[every] land] -. Prostrate are the Temeh, slain in their places in heaps before his horses, causing them to cease boasting in their land. His arm has laid low

25 Ver fig. 2.4. W.F. EDGERTON y J. A. WILSON, Historical Records of Ramses III. The Texts in Medinet Habu. Volumes I and II, Chicago 1936, p. 7-8. La imagen puede consultarse en EPIGRAPHIC SURVEY, Medinet Habu, Volume I, Earlier Historical Records of Ramses III, Chicago 1930, plate 16. Aquí seguimos las tesis expuestas por Vandersleyen en el trabajo citado: la presencia de estas tribus en el Delta solo está documentada a partir del Tercer Período Intermedio.

26 Ver J. H. BREASTED, Ancient Records of Egypt, Volume IV, New York 1962 (1906), \# \# 59, p. 33

27 Ver N.K. SANDARS The Sea Peoples. Warriors of the Ancient Mediterranean 1250-1150 BC. London, 1978, p. 188.

28 Ver fig. 2.5. W.F. EDGERTON y J. A. WILSON, Historical Records of Ramses III. The Texts in Medinet Habu. Volumes I and II, Chicago 1936, p. 9. La imagen puede consultarse en EPIGRAPHIC SURVEY, Medinet Habu, Volume I, Earlier Historical Records of Ramses III, Chicago 1930, plate 17. Ver también J. H. BREASTED, Ancient Records of Egypt, Volume IV, New York 1962 (1906), \# 49, p. 27.

29 Ver fig. 2.9. W.F. EDGERTON y J. A. WILSON, Historical Records of Ramses III. The Texts in Medinet Habu. Volumes I and II, Chicago 1936, p.24. La imagen puede consultarse en EPIGRAPHIC SURVEY, Medinet Habu, Volume I, Earlier Historical Records of Ramses III, Chicago 1930, plate 27-28. Ver también J. H. BREASTED, Ancient Records of Egypt, Volume IV, New York 1962 (1906) \# 40, p. 22. 
their seed through the strength of his father Amon, who has given to him every land gathered together; Lord of the [Two] Lands: Usermare-Meriamon.» ${ }^{30}$

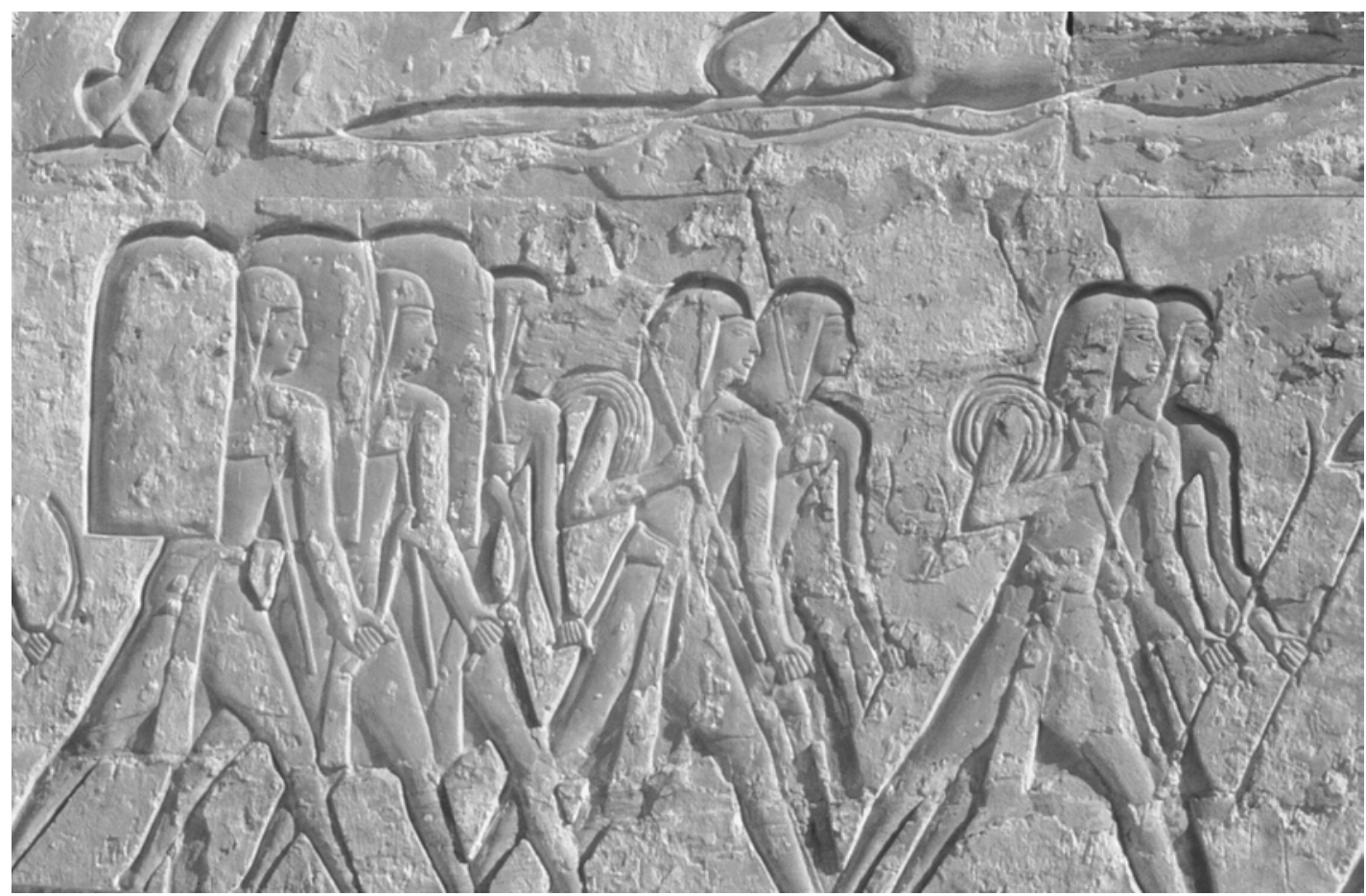

Fig. 9. Soldados de infantería egipcios (Foto: J. Trello).

La Gran Inscripción del Segundo Patio de Medinet Habu recoge, utilizando metáforas recurrentes de la imaginería egipcia, el sometimiento del enemigo:

«Now the heart of his majesty was terrible and mighty [like] a lion hidden and prepared [for] small catlle. He was ready like a bull, mighty of arms and sharp of horns, to attack the (very) mountains in pursuit of him who assailed him. The gods derided their plans, for they caused his might to be against the one who violated his frontier. His majesty went forth against them like a flame [found scattered] in the thick brush, - like birds within a net. They were threshed as sheaves, made ashes, and cast down prostrate in their (own) blood. Their overthrow was heavy, without limit. Behold, they were in evil case to the height of heaven, for their thick mass was gathered together in the place of slaughtering them, and they were made into pyramids on their (own) soil by the might of the King, valiant in his person, sole lord, powerful like Montu, King of Upper and Lower Egypt: Usermare-Meriamon; Son of Re: Ramses $I I I »^{31}$.

30 Ver fig. 2.7. W.F. Edgerton y J. A. WILSON, Historical Records of Ramses III. The Texts in Medinet Habu. Volumes I and II, Chicago 1936, p. 10-11. La imagen puede consultarse en EPIGRAPHIC SURVEY, Medinet Habu, Volume I, Earlier Historical Records of Ramses III, Chicago 1930, plate 18. Ver también J. H. BREASTED, Ancient Records of Egypt, Volume IV, New York 1962 (1906)\# 50, p. 28.

31 Ver fig. 2.9. W.F. EdGerTon y J. A. WILSON, Historical Records of Ramses III. The Texts in Medinet Habu. Volumes I and II, Chicago 1936, p. 26. La imagen puede consultarse en EPIGRAPHIC SURVEY, Medinet Habu, Volume I, 
En la misma inscripción se recoge la derrota del enemigo, en cuya boca se ponen declaraciones muy interesantes:

"The land of Temeh fled; they ran, the Meswesh [were in suspense],- in their land. Their root was cut off; they are not, in a single case. Every part of their bodies is weak from the terror. "She who breaks our back, say they, with reference to Egypt, whose lord has destroyed our soul forever and ever.» It goes ill with them, when they see their [slayers like the slaughterers of Sekhmet, who were in pursuit of them. One is awe-struck and afraid] before them. "If our tread shall find no way to go, we shall [traverse] the lands to their limits. Their warriors will not fight with us in [any] fray. There attacks us our own fire of our own desire, and we are desolate! Our heat is taken away; our strength is not! Their lord is like Set, the beloved of Re, his battle cry is heard like (that of) a griffon. He is after us, slaughtering; he has no pity! He makes us turn back [from mentioning] Egypt forever. Foolish were the hurlings of ourselves toward death [and making the fire which we (ourselves) entered]...»32

El texto parece sugerir que los ahora enemigos han formado parte del ejército de Faraón con anterioridad. Esta incorporación pudo producirse tras las guerras de Merenptah, al igual que Ramses III hizo con los prisioneros enemigos que sobrevivieron. El texto también recoge los nombres de cinco jefes enemigos, cuya ubicación en unas coordenadas temporales es controvertida ${ }^{33}$.

El resultado de la batalla fue desastroso para los libios; según las fuentes 12.535 muertos. No sabemos el número de bajas en el ejército de Faraón.

Terminada la batalla el rey, aún en su carro, sentado de espaldas a los caballos, se dirige a los jefes de su ejército triunfador (Fig. 10):

"Words spoken by the King, Lord of the Two Lands: Usermare-Meriamon; Son of Re, Lord of Diadems: Ramses III, to the royal princes, the royal chamberlains, the officials, the companions, and all the leaders of the infantry and chariotry. "Rejoice te to the height of heaven, for my arm has overthrown the Tehenu, who came prepared, their hearts confident, to [lift themselves up (in rivalry) with] Egypt. I went forth against them like a lion. I threshed them, made into sheaves. I was after them like a divine falcon when he has sighted small birds at a [hole]. My sword - - - until it [is put to rest]. My arrow does not miss in their limbs. My heart bellows like a bull on the field of battle, like Set when he rages. I have rescued my infantry, I [have protected] the chariotry, and my arms have covered the people over. I have cast down their souls; I have taken away their strength; my heat has burned up their villages. I am like Montu as king in Egypt; the terror of me has overthrown the Nine Bows; and Amon-Re, my august father, [makes] prostrate every land under my feet, while I am king upon [his] throne forever» ${ }^{34}$.

Later Historical Records of Ramses III, Chicago 1930, plate 27-28. Ver también Ver J. H. BREASTED, Ancient Records of Egypt, Volume IV, New York 1962 (1906) \# 41, p. 22.

32 Ver fig. 2.9. W.F. EDGERTON y J. A. WILSON, Historical Records of Ramses III. The Texts in Medinet Habu. Volumes I and II, Chicago 1936, p. 28-29. La imagen puede consultarse en EPIGRAPHIC SURVEY, Medinet Habu, Volume I, Earlier Historical Records of Ramses III, Chicago 1930, plate 27-28. Ver también J. H. BREASTED, Ancient Records of Egypt, Volume IV, New York 1962 (1906) \# 43, p. 23.

33 Ver J. H. BREASTED, Ancient Records of Egypt, Volume IV, New York 1962 (1906) nota «b» de la p. 24

34 Ver fig. 2.10. W.F. EDGERTON y J. A. WILSON, Historical Records of Ramses III. The Texts in Medinet Habu. Volumes I and II, Chicago 1936, p. 16. La imagen puede consultarse en EPIGRAPHIC SURVEY, Medinet Habu, Volume I, Earlier Historical Records of Ramses III, Chicago 1930, plate 23. Ver también J. H. BREASTED, Ancient Records of Egypt, Volume IV, New York 1962 (1906) \# 54, p. 31. 


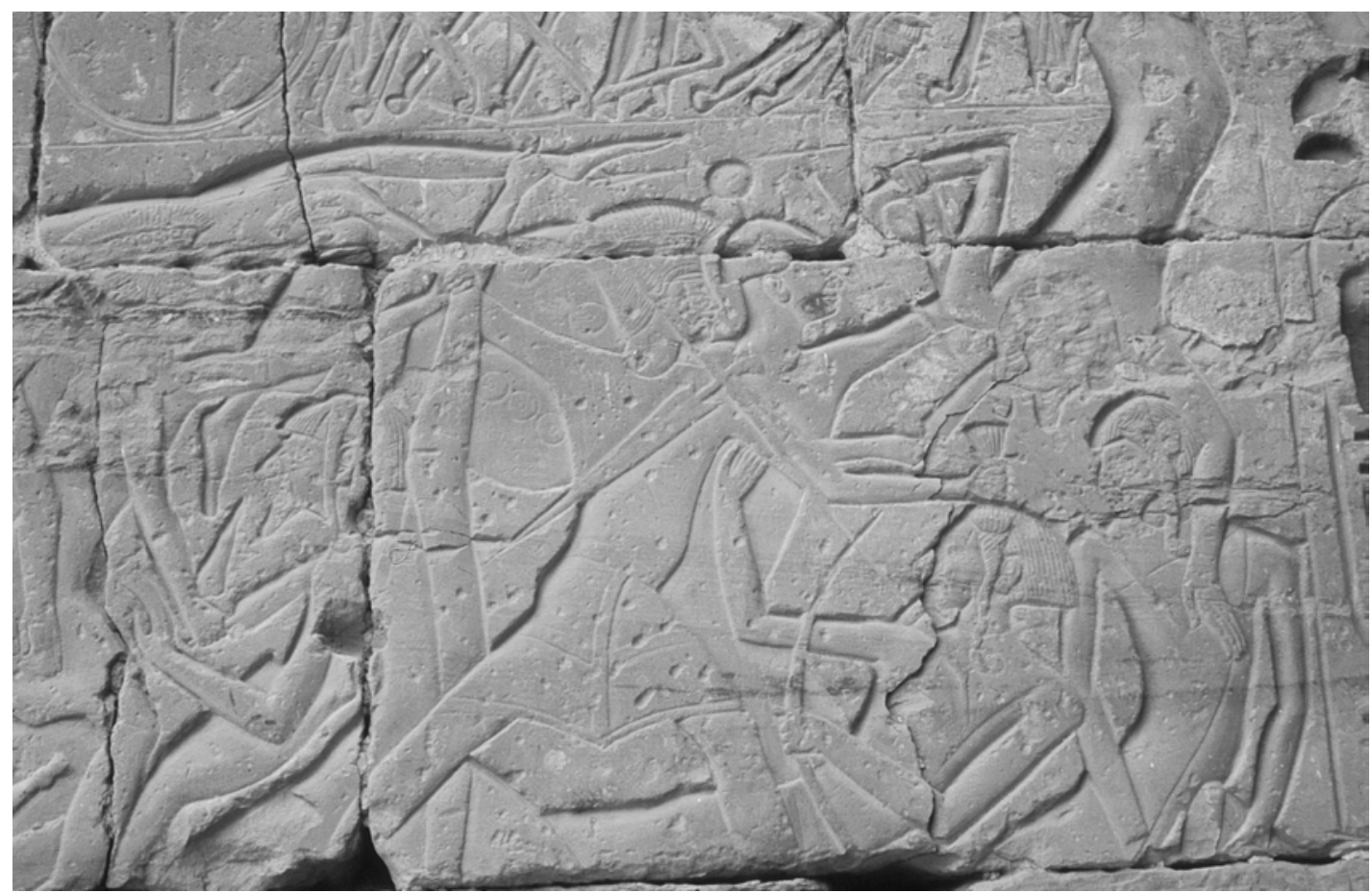

Fig. 10. Soldados pelsetu y shardana luchando en el ejército egipcio contra los libios (Foto: J. Trello).

Los oficiales hacen el macabro recuento de manos y falos (Fig. 11) ${ }^{35}$ : Libya,

«Presenting the spoil in the presence of his majesty, consisting of the fallen ones of

amounting to 1,000 men,

amounting to 3,000 hands,

amounting to 3,000 phalli.» 36

El rey recién bajado de su carro de guerra se asoma al balcón y expresa en un discurso ante la corte el resultado de la experiencia bélica:

Words spoken by his majesty to the officials and companions who are at his side: «See ye the many benefactions which Amon-Re, the King of the Gods, perfomed for Pharaoh, his child. He has carried off the land of Temeh, Seped, and Meshwesh, who were robbers, ruining Egypt daily, but were made prostrate under my feet. Their root is cut off; they ar not, in a single case. Their feet have ceased to tread Egypt forever, thorugh the goodly counsels

35 Se entiende «mano mutilada de enemigo». Igualmente se entiende «falo con pellejo», es decir sin circuncidar, para lo cual utilizaban el término hnnw m krnt. Recordemos que los egipcios se circuncidaban. Ver J.M. GALAN «Los enemigos de Egipto en Epoca Antigua», en: M.J. LÓPEZ GRANDE (ed.) Culturas del Valle del Nilo I; su historia, relaciones externas e investigación española. Universidad Autónoma de Madrid (e.p.), p. 14.

36 Ver fig. 2.10. W.F. EDGERTON y J. A. WILSON, Historical Records of Ramses III. The Texts in Medinet Habu. Volumes I and II, Chicago 1936, p. 15. La imagen puede consultarse en EPIGRAPHIC SURVEY, Medinet Habu, Volume I, Earlier Historical Records of Ramses III, Chicago 1930, plate 23. Ver también J. H. BREASTED, Ancient Records of Egypt, Volume IV, New York 1962 (1906) \# 54, p. 31. 
which his majesty made to take care of [Egyp]t, which had been wasted. Rejoice and exult ye to the hei [ght of] heaven, for I have appeared like Montu, extending Egypt. My arm is great and powerful, overthrowing the Nine Bows, through that which my father, the Lord of the Gods, Amon-Kamephis, the creator of my beauty, has done for me» ${ }^{37}$.

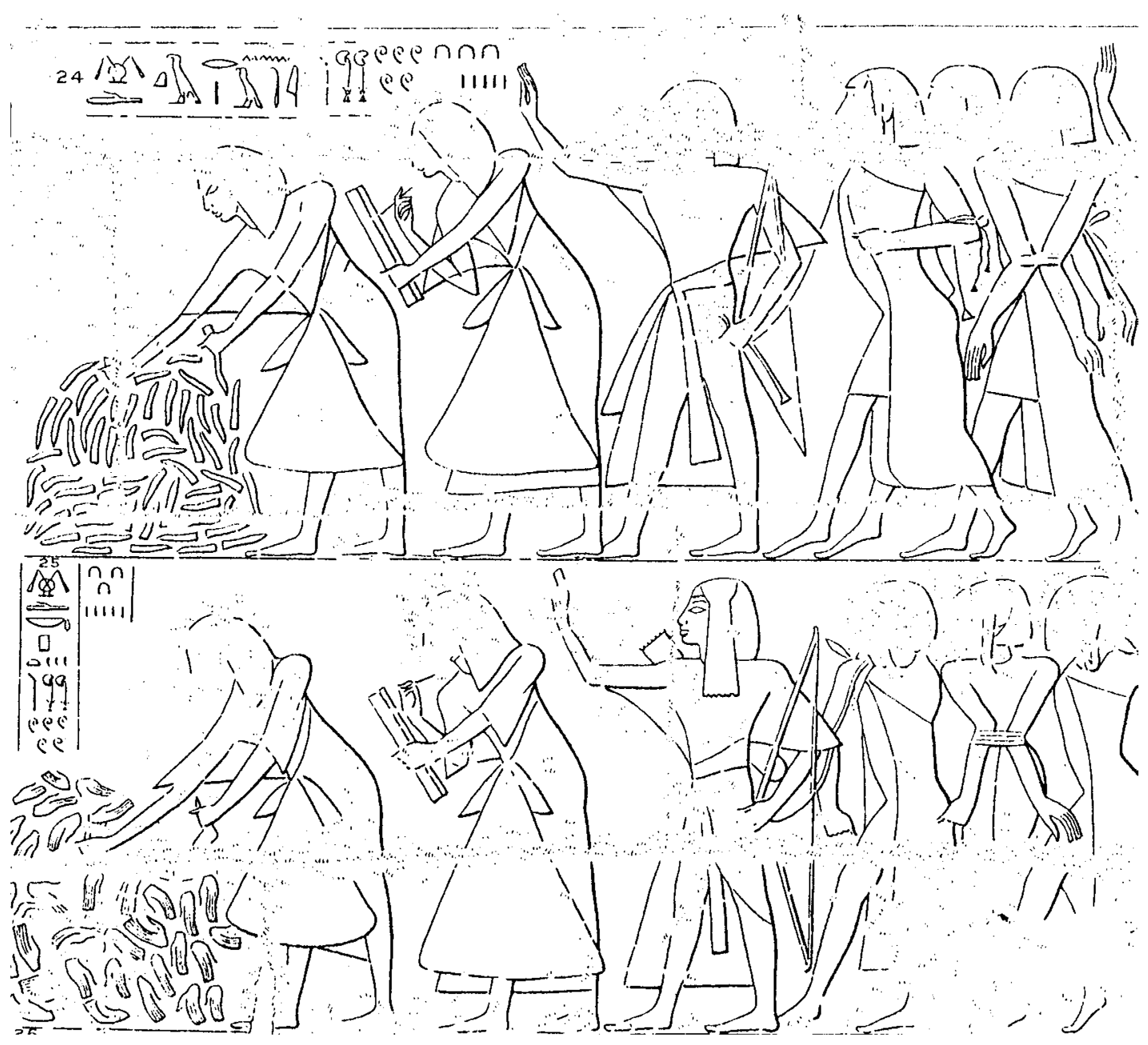

Fig. 11. Recuento de penes y manos cortadas a los enemigos (Ibidem. Pl. 22b).

Finalmente, Ramses III agradece el triunfo a Amón-Ra, rey de los dioses:

«Words spoken by the King of Upper and Lower Egypt, Lord of the Two Lands: Usermare-Meriamon, in the presence of his father Amon-Re, Ruler of the Ennead: «How great is that which thou hast done, $O$ Lord of the Gods! Thy plans and thy counsels are those which

37 Ver fig. 2.12. W.F. EDGERTON y J. A. WILSON, Historical Records of Ramses III. The Texts in Medinet Habu. Volumes I and II, Chicago 1936, p. 13. La imagen puede consultarse en EPIGRAPHIC SURVEY, Medinet Habu, Volume I, Earlier Historical Records of Ramses III, Chicago 1930, plate 22. Ver también J. H. BREASTED, Ancient Records of Egypt, Volume IV, New York 1962 (1906) \# 52, P. 29. 


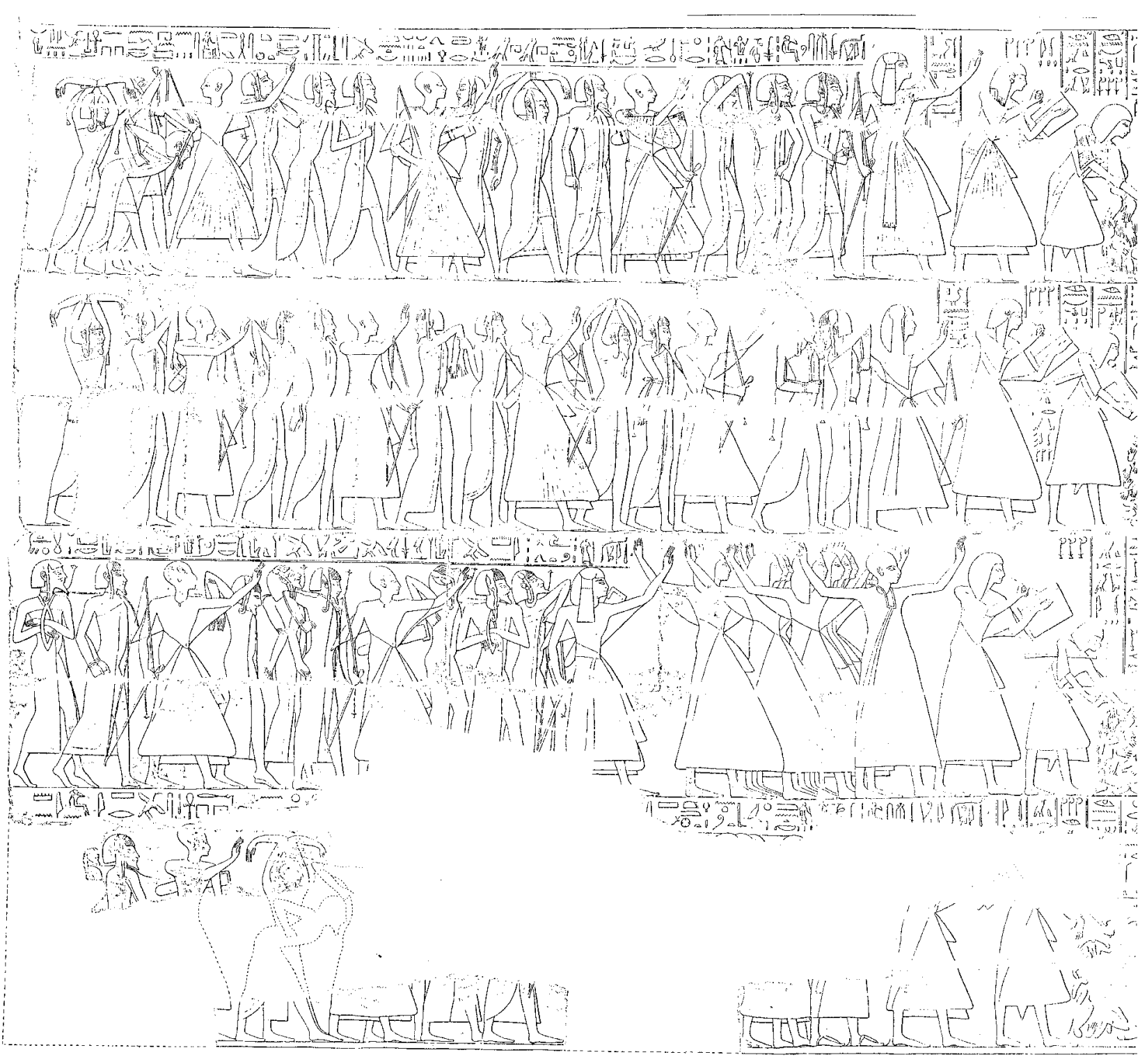

Fig. 12. Ramses III celebrando su victoria 
come to pass, since thou hast sent me forth in valor, thy sword with me, for no land can stand before me at the memory of thee. I have cast down the violators of my frontier, prostrate in their places, their runners pinioned and slain in my grasp. I haver overthrown the land of Temeh; their seed is not. As for the Meshwesh, they [are in travail] for terror of me. He who has relied upon that which thou hast commanded has victory; everyone who [is failthful to thee] has kingship» ${ }^{38}$.

El rey dejó constancia de sus victorias contra los pueblos del desierto occidental haciendo grabar inscripciones que, probablemente, repetirían de forma mágica la derrota infligida a sus enemigos. Además, obliga a los vencidos a adoptar el idioma egipcio. Esto último es lo que parece deducirse del contexto donde se ha encontrado la siguiente inscripción: una estela en el santuario rupestre de Meretseger, cerca de Deir el-Medina. Dice así:

«He plundered the foreing lands [...] Libyans and Mesues. He has caused that they cross the river canals and were brought to Egypt. They were made into royal serfs, and they have listened [to the speech of the] people at the service of the king. He makes their speech disappear, he chan[ges] their tongues, and they march on the road without their turning back» ${ }^{39}$.

Por último nombra ${ }^{40}$ un nuevo jefe de los tchemehu entre los vencidos.

\subsection{Las guerras contra los llamados «pueblos del mar»}

Ramses III tuvo que afrontar el más duro choque militar y, con toda seguridad una de las batallas claves en la historia de Egipto, en el año 8 de su reinado.

"Year 8 under the majesty of the Horus: Mighty Bull, strong lion, mighty of arm, possessor of a strong arm, taking captive the Asiatics; Favorite of the Two Goddesses: Rich in Strength like His Father Montu, destroying the Nine Bows, driven from their land; Horus of Gold: Divine When He Issued form the Womb, the son, excellent and legitimate, of Harakhte, the sovereign, the beneficent heir of the gods, fashioning their images upon earth, doubling their offerings; King of Upper and Lower Egypt, Lord of the Two Lands: UsermareMeriamon: Son of Re: Ramses III ${ }^{41}$.

Ya teníamos noticia de la ayuda prestada por los thekel y pelsetu a Themer, el rey de la confederación libia en la guerra del año 5. Sin embargo, también vemos a los peleset formar parte, perfectamente encuadrados con los soldados shardana, en una división del ejército egipcio durante el ataque a las poblaciones nubias. Dado que las escenas en Medinet Habu parecen estar situadas en orden cronológico, y las guerras nubias están situadas antes que las guerras del año 5, hay que suponer que los peleset formaron parte del ejército egipcio, antes de los enfrentamientos con él en el año 11.

38 Ver fig. 2.13. W.F. EdGERTON y J. A. WILSON, Historical Records of Ramses III. The Texts in Medinet Habu. Volumes I and II, Chicago 1936, p. 18. La imagen puede consultarse en EPIGRAPHIC SURVEY, Medinet Habu, Volume I, Earlier Historical Records of Ramses III, Chicago 1930, plate 26. Ver también J. H. BREASTED, Ancient Records of Egypt, Volume IV, New York 1962 (1906) \# 58, p. 33.

39 Ver J.M. GALAN «The Use of šalamu and baraka in Ancient Egyptian Texts» Zeitschrift für ägyptische Sprache 124 (1997), p. 39. Ver también J. TRELLO, «Meretseger; La que ama el silencio» Revista de Arqueología, n. ${ }^{\circ}$ 232, Agosto 2000 , pp. $34-35$.

40 Ver J.M. GALAN «Los enemigos de Egipto en Epoca Antigua», en: M.J. LóPEZ GRANDE (ed.) Culturas del Valle del Nilo I; su historia, relaciones externas e investigación española. Universidad Autónoma de Madrid (e.p.) nota 75.

41 Ver fig. 2.14. W.F. EDGERTON y J. A. WILSON, Historical Records of Ramses III. The Texts in Medinet Habu. Volumes I and II, Chicago 1936, p. 49. La imagen puede consultarse en EPIGRAPHIC SURVEY, Medinet Habu, Volume I, Earlier Historical Records of Ramses III, Chicago 1930, plate 46. 


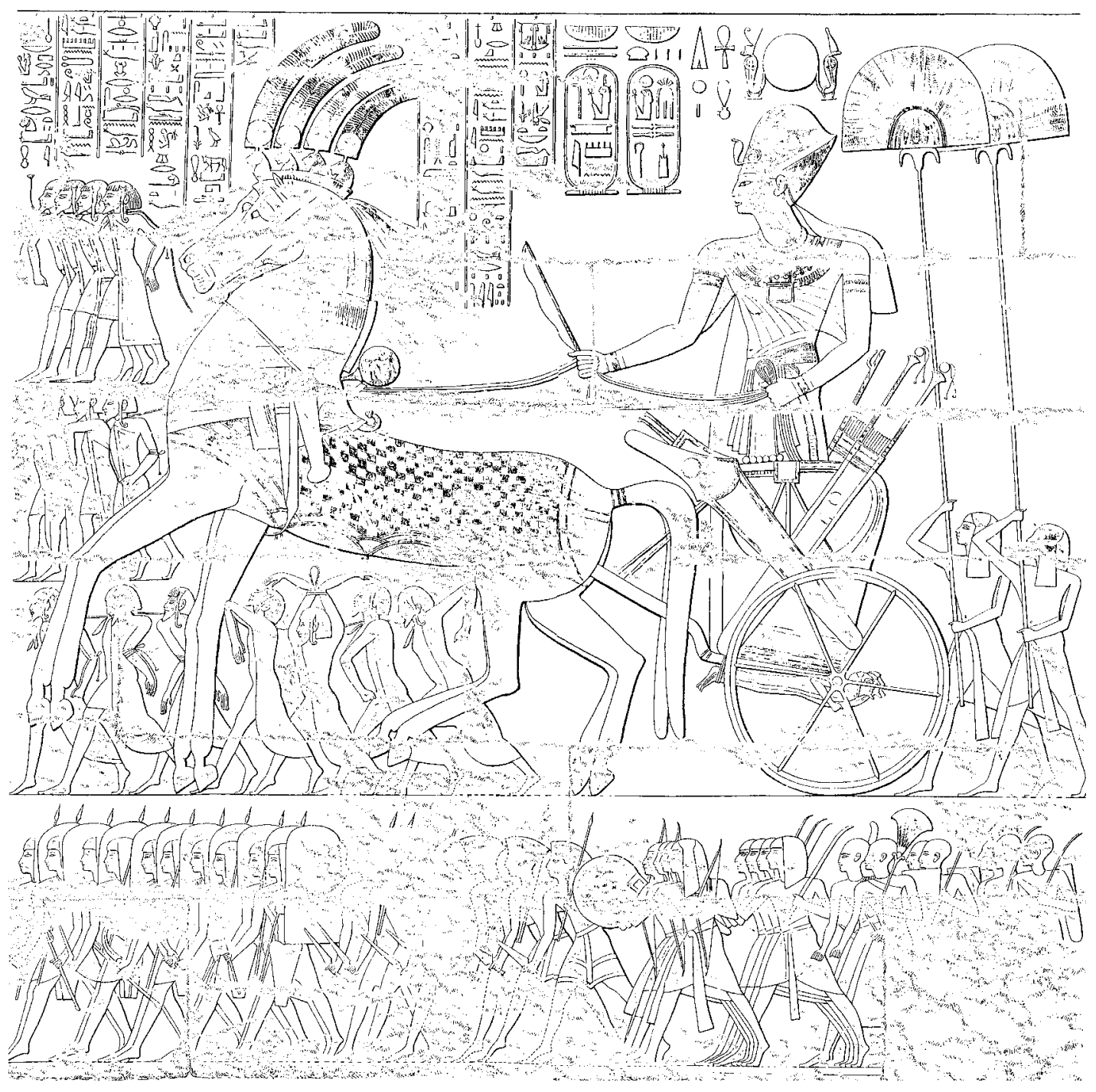

Fig. 13. Regreso triunfal de la guerra contra los libios (Ibidem. Pl. 24).

En las guerras contra los Pueblos del Mar, los peleset y los thekel eran los protagonistas principales de la mayor amenaza que Egipto había tenido, quizás en los últimos siglos. Esta amenaza habría llevado a dotar de fortalezas ${ }^{42}$ y de sistemas de alerta, la costa mediterránea del delta del Nilo.

42 Sobre el apasionante y controvertido tema de los «Pueblos del Mar» se han escrito auténticos ríos de tinta. Ver S. Gitin, A. MAZAR y E. STERN (ed.) Mediterranean Peoples in transition. Thirteenth to Early Centuries BCE, Jerusalem 1998 y N.K. SANDARS The Sea Peoples. Warriors of the Ancient Mediterranean 1250-1150 BC. London, 1978. Recientemente se ha planteado la posibilidad de que Rhacotis constituyera la principal fortaleza contra los ataques de los «pueblos del mar» en la costa egipcia mediterránea. Ver Lutfi Abdul-Wahab YEHIA «Rhacotis: An Egyptian Stronghold against the Attacks of the Sea-People» en Proceedings of the Eighth International Congress of Egyptologists, Cairo 28 marzo-3 abril 2000, (e.p.). 
Ramses III tuvo que enfrentarse no solo contra la invasión de un ejército, sino contra una arrolladora ola de pueblos desplazados y en marcha, que habían arrasado antiguas civilizaciones, sólidamente constituidas, en Asia Menor, Siria y las islas del Mediterráneo Oriental.

Tenía ante las puertas de Egipto a los miles de desplazados que vagaban por el Mediterráneo tras el hundimiento de la civilización micénica. El gran imperio hitita, que tras el tratado de paz entre Ramses II y Hattusilis III había constituído un poderoso escudo protector en Asia Menor, se había desmoronado.

Con el tratado de paz, Ramses II había conseguido que la zona siro-palestina, desde Biblos al norte (incluso Beth-Shan y Damasco) hasta el Negev al sur, quedara como una especie de provincia ${ }^{43}$ egipcia. Faraón conservó dinastías locales, bajo la estricta vigilancia de los funcionarios egipcios, a cambio de recibir tributos.

Pero ahora las cosas habían cambiado. Los Pueblos del Norte no solo habían destruido ${ }^{44}$ Hatti, sino que en su avance habían acabado con Arzawa, Karkemish y Alashia. Habían llegado a Amurru y la habían devastado ${ }^{45}$. Desde allí se preparaban para atacar la única civilización organizada que quedaba en el Mediterráneo Oriental.

Hemos podido seguir el paso de esta destrucción no solamente a través de las fuentes egipcias, sino también a través de los dramáticos informes que enviaban los angustiados habitantes de las ciudades que avistaron a los invasores e intuyeron el triste final que les esperaba.

«As for the foreign countries, they made a [conspiracy] in their isles. [Removed] and scattered in the fray were the lands at one time. No land could stand before their arms, from Hatti, Kode, Carchemish, Yereth, and Yeres on, (but they were) cut off at [one time]. A camp [was set up] in one place in Amor. They desolated its people, and its land was like that wich has never come into being. They were coming, while the flame was prepared before them, forward toward Egypt.

"Their confederation was the Peleset, Theker, Shekelesh, Denye(n), and Weshesh, lands united. They laid their hands upon the lands to the (very) circuit of the earth, their hearts confident and trusting: «Our plans will succeed!» ${ }^{46}$.

Se ha especulado mucho sobre las causas y el origen de este movimiento de pueblos, pero realmente aún ${ }^{47}$ desconocemos mucho sobre el tema y su investigación no es objeto de este trabajo. Ahora bien, tenemos hechos poco cuestionables como son la destrucción del imperio hitita y de las ciudades amoritas, constatadas arqueológicamente y por registros escritos de otras fuentes que concuerdan con las fuentes egipcias.

43 Ver N.K. SANDARS The Sea Peoples. Warriors of the Ancient Mediterranean 1250-1150 BC. London, 1978, p. 45.

44 Se ha discutido mucho sobre el relato de la destrucción de los estados del Oriente Próximo por los «Pueblos del Mar». Esta destrucción parece confirmarse por las cartas encontradas en los archivos de Râs Shamra, de Râs Ibn Hani y de Boghaz-Köy, en las que se puede seguir la caída de Hatti, Chipre y Ugarit, de manera dramática, bajo las fuerzas devastadoras de los šikalaju, denominados tkrw en las fuentes egipcias. Ver P. GRANDET, Le Papyrus Harris I (BM 9999), Le Caire 1994, Vol. II, p. 242.

${ }^{45}$ La geografía histórica no permite dar una opinión unánime acerca de la identificación de las ciudades citadas. No obstante, la opinión más generalizada es que Arzawa era la Cilicia, situada en el sudeste de Anatolia, que Karkemish estaba sobre el recodo del Eufrates, y eran vasallos de los hititas y, por último, que Alashia era la isla de Chipre. Ver S. WACHSMANN, Aegeans in the theban tombs, Leuven 1987, pp. 93-102.

46 Ver fig. 2.14. W.F. EDGERTON y J. A. WILSON, Historical Records of Ramses III. The Texts in Medinet Habu. Volumes I and II, Chicago 1936, p. 53. La imagen puede consultarse en EPIGRAPHIC SURVEY, Medinet Habu, Volume I, Later Historical Records of Ramses III, Chicago 1930, plate 46. Ver también Ver J. H. BREASTED, Ancient Records of Egypt, Volume IV, New York 1962 (1906), \# 64, p. 37.

47 Ver F. QUESADA «Egipto y el Egeo durante el Bronce Reciente. Datos y debates para un estado de la cuestión» en M.J. LÓPEZ GRANDE (ed.) Culturas del Valle del Nilo I; su historia, relaciones externas e investigación española. Universidad Autónoma de Madrid (e.p.) 
Pero ¿dónde se había originado el fenómeno que enviaba a las fronteras egipcias oleadas de pueblos buscando una tierra donde asentarse?. La respuesta hay que buscarla allende los mares, quizás en la Europa Central y Septentrional, donde muchos pueblos ${ }^{48}$ parecen haberse puesto en marcha, empujando a otros hacia el sur. No es, en todo caso, el objetivo de este trabajo.

No se trataba de un grupo étnico homogéneo, sino de una oleada de pueblos que, en su avance, había destruido la civilización asentada sobre la cuenca del Mediterráneo Oriental ${ }^{49}$, atacando por tierra y por mar a las ciudades sirias del litoral. Desde allí preparaban el asalto a Egipto y la posesión de los preciados y extensos campos del Delta. Los Pueblos del Norte fletaron los barcos cargados de soldados dispuestos a destruir cualquier barrera que se opusiera al avance de su marcha. Mientras, por tierra, avanzaban otros grupos de guerreros acompañando al resto del pueblo; mujeres, niños, ancianos, así como los ganados y todos sus enseres en las carretas tiradas por bueyes, confiando en la segura victoria de la milicia que penetraba por las bocas del Nilo ${ }^{50}$.

Ramses III se puso a la cabeza de su ejército para enfrentarse a los invasores, los cuales debían tener su campamento principal en algún lugar de Canaan ${ }^{51}$.

A juzgar por las grandiosas representaciones de Medinet Habu, la guerra se decidió en dos grandes batallas: una terrestre y una naval, en ese orden.

Los lugares donde se produjeron las batallas debieron ser dos puntos no muy lejanos entre sí y, en ambos encuentros interviene el rey, si bien de manera diferente, porque en la batalla terrestre interviene directamente y en la batalla ${ }^{52}$ naval apoya desde la costa a su marina de guerra.

Los relieves de Medinet Habu nos muestran la preparación de la batalla (Fig. 14), en detalle y de manera secuencial. Primero aparece el rey, en su balcón, protegido por los dioses, y arengando a sus tropas. Los jefes del ejército contestan reafirmando ante el monarca su completa disposición para la guerra y la confianza absoluta en su rey.

A continuación se transmiten las órdenes en cascada, con orden y rapidez utilizando los imperiosos mandatos de las trompetas de órdenes.

Ramses III convocó y preparó a su ejército para la batalla. Los soldados encargados de transmitir las órdenes marcan los distintos momentos de la ceremonia y los movimientos de tropas, con los sonidos de sus alargadas trompetas. Las unidades, en formación, esperan las instrucciones de Faraón. Allí estaban los príncipes de Egipto y los jefes de los cuerpos de infantería y del ejército de carros. También estaban los nuevos reclutas con sus oficiales al mando de cada grupo, en correcta formación. Entonces, Faraón se asomó a la Ventana de las Apariciones, lanzó una arenga ${ }^{53}$ y ordenó la distribución de (Fig. 14) armas a las tropas:

48 Ver M. BENDALA, »Los albores de Grecia» Historias del Viejo Mundo. Historia $16 n^{\circ}$ 9, p. 100.

49 Una corriente muy fuerte de este movimiento se produjo en el oeste de Anatolia (los lukka y los teresh o tursha), que presionaron sobre el imperio hitita y sobre el corredor sirio-palestino. En este sentido, incluso los troyanos de $L a$ Iliada se pueden adscribir al grupo de «Pueblos del Mar» en lucha directa con los griegos (micénicos o aqueos). Ver J. Ma BlazQueZ, R. Lopez MELERO y J.J. SAYAS, Historia de la Grecia Clásica, Madrid 1989, p. 248.

50 Ver J. H. BREASTED, Ancient Records of Egypt, Volume IV, New York 1962 (1906), \# 62, p. 36.

51 Ver I. FINKELSTEIN «Philistine Chronology: High, Middle, or Low?» en S. GITIN, A. MAZAR y E. STERN (ed.) Mediterranean Peoples in transition. Thirteenth to Early Centuries BCE, Jerusalem 1998, p. 143.

52 Hay que señalar que los investigadores no están totalmente de acuerdo en la identificación del lugar donde se produjeron estas batallas. Mientras que Singer (1994:291) opina que se dio en un lugar norteño, Redford (1985:217) y Bietak (1993:293) consideran que ambas tuvieron lugar en el Delta. Ver también I. FINKELSTEIN «Philistine Chronology: High, Middle, or Low?» en S. GITIN, A. MAZAR y E. STERN (ed.) Mediterranean Peoples in transition. Thirteenth to Early Centuries BCE, Jerusalem 1998, p. 143.

53 Ver fig. 2.15. W.F. EDGERTON y J. A. WILSON, Historical Records of Ramses III. The Texts in Medinet Habu. Volumes I and II, Chicago 1936, p. 35. La imagen puede consultarse en EPIGRAPHIC SURVEY, Medinet Habu, Volume I, Earlier Historical Records of Ramses III, Chicago 1930, plate 29. Ver también J. H. BREASTED, Ancient Records of Egypt, Volume IV, New York 1962 (1906) \# 71, p. 41. 


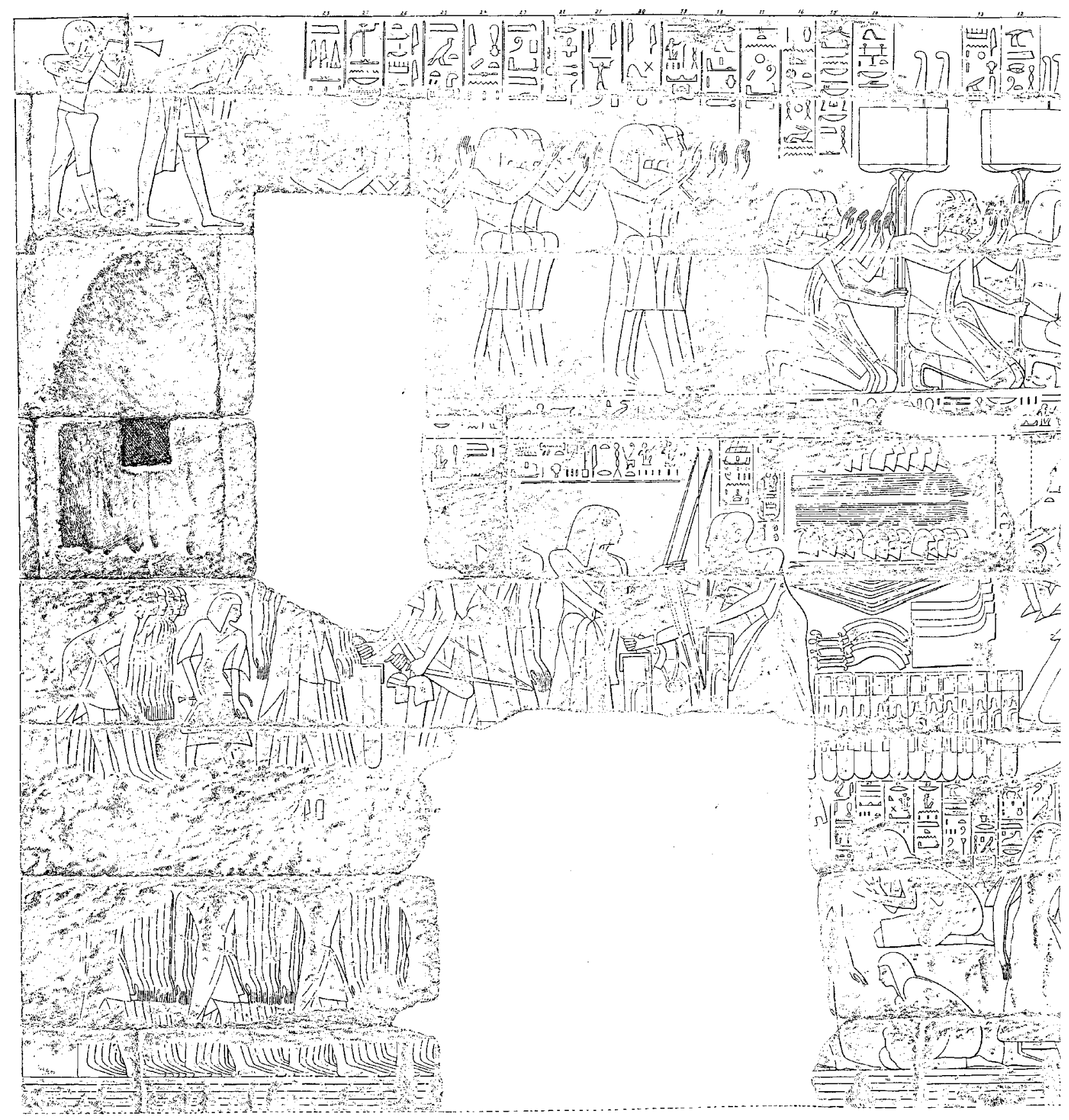

Fig. 14. Preparativos de la guerra contra 


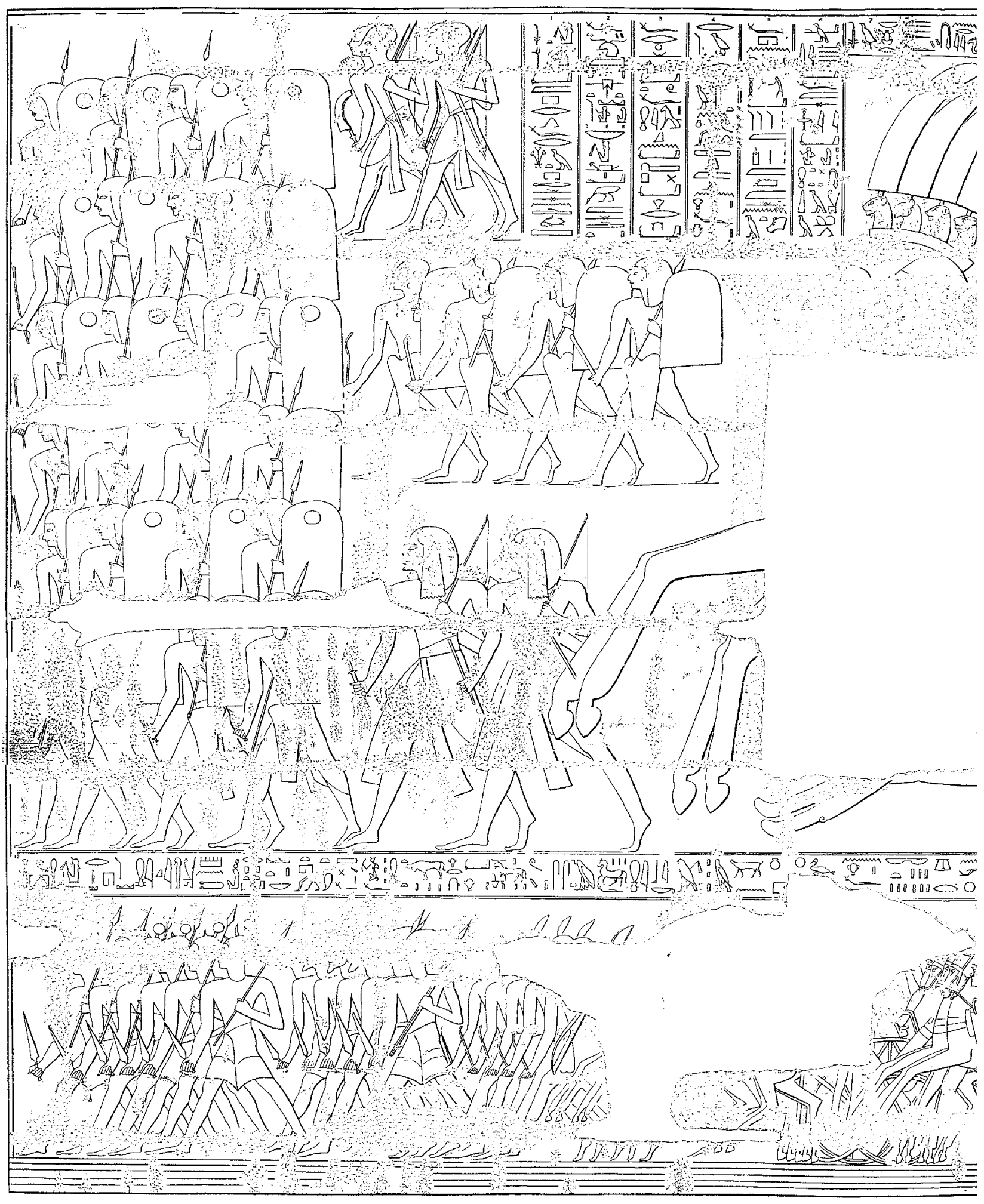

Fig. 15. El ejército egipcio mar 


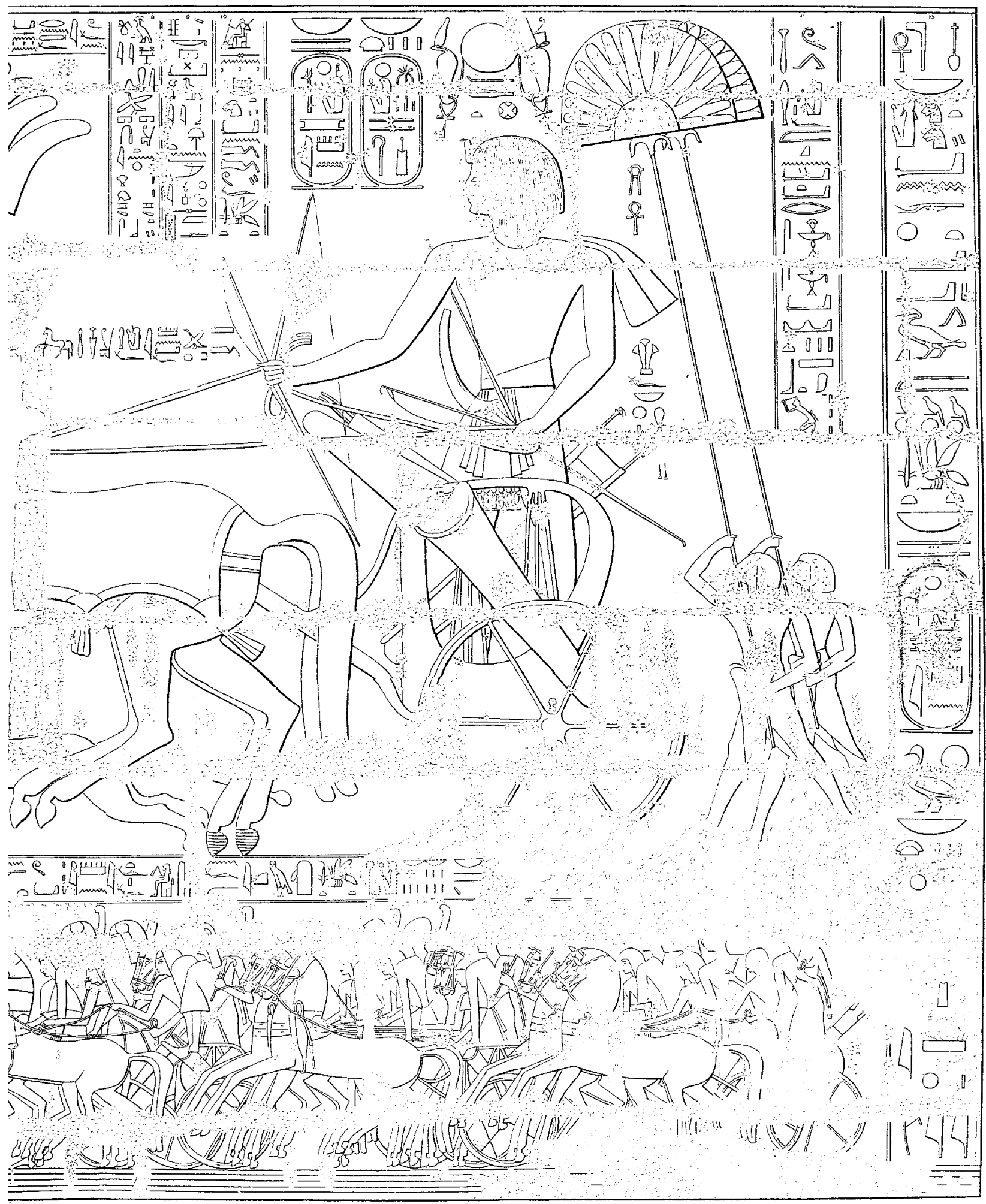

cha hacia Dyahi (Ibidem, Pl, 31). 
The King himself says to the officials, the companions and every leader of the infantry and chariotry who is in the presence of his majesty: «Bring forth equipment! Send out troops to destroy the rebellious [countries] which know not Egypt, through the strength of my fa[ther A]mon!».

- - - - [Usermare-Meri]amon, the mighty bull, crushing the Asiatics, lord of [-] in the lands, like - - - - - -entering [into] the midst - - . - - -.

Es un príncipe, hijo del Rey, quién se encarga de dirigir las operaciones de equipamiento de las tropas.

The Crown Prince, Great Royal Scribe, and Royal Son - he says to the commanders of the army, the captains of the troops, and the officers of the troops: "One speaks thus, narmely] Pharaoh: "Every picked man, good [-], every valiant one who is in the knowledge of his majesty, let them pass by in the presence of Pharaoh to [receive] equipment.»

Inmediatamente los oficiales transmiten las órdenes:

- - - [giving equipment to the infantry and chariotry, to the troops, the Sherden, and the Nubians.

Los armeros comienzan a distribuir los equipos de guerra, que, adecuadamente apilados, habían permanecido en las armerías de Faraón (Fig. 14). Los cascos, los escudos, las lanzas, las terribles espadas curvas, los arcos, las aljabas y flechas son distribuidas:

[Receiving equipment [in the presence of] Usermare-Meriamon, rich of strength.

Los reclutas reciben, con su jefe al frente, el armamento que corresponde a su especialización en la guerra. Las salidas de armas son escrupulosamente registradas por los escribas del ejército. Faraón es puntualmente informado de la situación de las operaciones:

The infantry and chariotry, who are receiving [equipment] in the presence of [his] majesty.

Es realmente impresionante la escena de movilización del ejército egipcio y observar cómo se distribuyen, de manera ordenada, las armas perfectamente apiladas: espadas, escudos, aljabas, etc., bajo la atenta mirada y el minucioso registro de los escribas del ejército. Esto nos lleva a suponer que los soldados no disponían habitualmente de las armas de guerra durante el tiempo de paz, o que la movilización fue de tal magnitud que requirió nuevos reclutas, habitualmente no armados.

Inmediatamente el ejército, encabezado por el rey, se pone en marcha hacia Dyahi (Fig. 15). Este lugar, posiblemente situado en el entorno de la actual franja de Gaza ${ }^{54}$, era una zona que anualmente había aportado a Egipto sus tributos ${ }^{55}$ en forma de productos agrícolas.

Ramses III sube ${ }^{56}$ a su carro de guerra y emprende la marcha hacia el frente al encuentro con el enemigo. Conduce personalmente su carro, ligero y tirado por dos magníficos cabalos, ricamente ataviados, que se dice es «The great chief span of his majesty, "Amon Gives the Sword».

\footnotetext{
54 Ver mapa en Manfred Bietak, MDAIK 47, 1991, p. 48, abb. 3. Otra posible ubicación podría haber sido en algún punto cercano a la actual Trípoli, en el Líbano. Ver Grandet, Op. Cit. Vol. II, 241. En cualquier caso en la planicie costera sirio-palestina.

55 Ver J.M. GALAN «Los enemigos de Egipto en Epoca Antigua», en: M.J. LOPEZ GRANDE (ed.) Culturas del Valle del Nilo I; su historia, relaciones externas e investigación española. Universidad Autónoma de Madrid (e.p.)

56 Ver Epigraphic Survey. Medinet Habu, Vol. I. Earlier Historical Records of Ramses III, Chicago 1930, Plate 31.
} 
Detrás de su carro marchan los cortesanos y el portador de las sandalias del rey. El ritual de guerra en Kemet no ha cambiado con el paso de los siglos. Sólo han cambiado las armas. En la simbólica representación iconográfica del rey Narmer, unos 1.800 años antes, aparece la misma imagen, como podemos ver en la famosa paleta de esquisto.

«His majesty sets out for Zahi like unto Montu, to crush every country that violates his frontier. His troops are like bulls ready on the field of battle; his horses are like falcons in the midst of small birds [before] the Nine Bows, bearing victory. Amon, his august father, is a shield for him; King of Upper and Lower Egypt, Ruler of the Nine Bows, Lord of the Two Lands. ${ }^{57}$.

Le rodea su magnífica infantería egipcia, armada con hachas, lanzas, escudos y sus arqueros, que portan entre su armamento, además de los arcos y flechas, las terribles espadas curvas.

En la primera línea del ejército marchan los mercenarios. Entre los mercenarios destacan los shardana, tropas de elite del rey, que abren la formación. Van provistos de largas espadas triangulares y escudos redondos, y protegidos por una coraza. Sobre la cabeza llevan un característico casco con dos cuernos y un disco central sobre un pequeño vástago. A continuación de la infantería mercenaria, avanza el ejército de carros egipcio, con una dotación de dos hombres por vehículo, el conductor y el guerrero combatiente. Son vehículos sumamente ligeros, con un tiro de dos caballos por carro. Los primeros carros van conducidos por los príncipes de Egipto ${ }^{58}$.

Ramses III parece que quiso asegurar primero ${ }^{59}$ la frontera oriental, y avanzó al frente de sus tropas para detener la invasión por tierra ${ }^{60}$. Por fin alcanzan al enemigo y se produce el choque contra los soldados y pueblos invasores (Fig. 16).

La batalla terrestre, en las llanuras de Dyahi, un lugar donde los ligeros carros de Faraón podían desplazarse velozmente, dio apreciable ventaja al ejército del rey sobre las pesadas carretas que transportaban tanto a las tropas como al paisanaje de los pueblos enemigos.

El rey carga contra los enemigos con su carro a toda velocidad ${ }^{61}$. Los caballos corren a galope tendido, las riendas atadas a la cintura del rey, quién se lanza sobre el enemigo tensando el arco y disparando sus flechas. Su enérgica intervención produce, según las escenas representadas por los egipcios, auténtico desconcierto entre las tropas de la confederación de Pueblos del Norte.

Junto al rey entra en combate todo el ejército de carros de Faraón. Los conductores lanzan los caballos sobre el enemigo al tiempo que protegen al guerrero con un escudo. Este último soldado lanza sus flechas sin parar desde su veloz plataforma. Mientras, la infantería egipcia ataca en formación, acompañados de las tropas de los mercenarios shardana, destrozando las defensas enemigas, alcanzando hasta la retaguardia. Allí la confederación de Pueblos de Norte disponen de pesadas carretas de dos ruedas, tiradas por bueyes, donde transportan a sus mujeres, sus niños y sus víveres. Inútilmente tratan de escapar de los soldados de Faraón. Algunos soldados enemigos huyen desesperados ante el irrefrenable ataque de la infantería del rey, que les persigue corriendo tras ellos.

57 Ver fig. 2.16. W.F. EdGERTON y J. A. WILSON, Historical Records of Ramses III. The Texts in Medinet Habu. Volumes I and II, Chicago 1936, p. 38. La imagen puede consultarse en EPIGRAPHIC SURVEY, Medinet Habu, Volume I, Earlier Historical Records of Ramses III, Chicago 1930, plate 31. Ver también J. H. BREASTED, Ancient Records of Egypt, Volume IV, New York 1962 (1906) \# 72, p. 42.

58 Ver J. H. BREASTED, Ancient Records of Egypt, Volume IV, New York 1962 (1906), \# 72, p. 43.

59 Ver N.K. SANDARS The Sea Peoples. Warriors of the Ancient Mediterranean 1250-1150 BC. London, 1978, p. 120.

60 Ver 2.17 Epigraphic Survey. Medinet Habu, Vol. I. Earlier Historical Records of Ramses III, Chicago 1930, Plate 32 .

${ }^{61}$ Este tipo de ataque ya fue utilizado por Thutmose III de la batalla de Megido (primera campaña asiática). Los faraones posteriores se preciaron de encabezar la carga como su antecesor. 

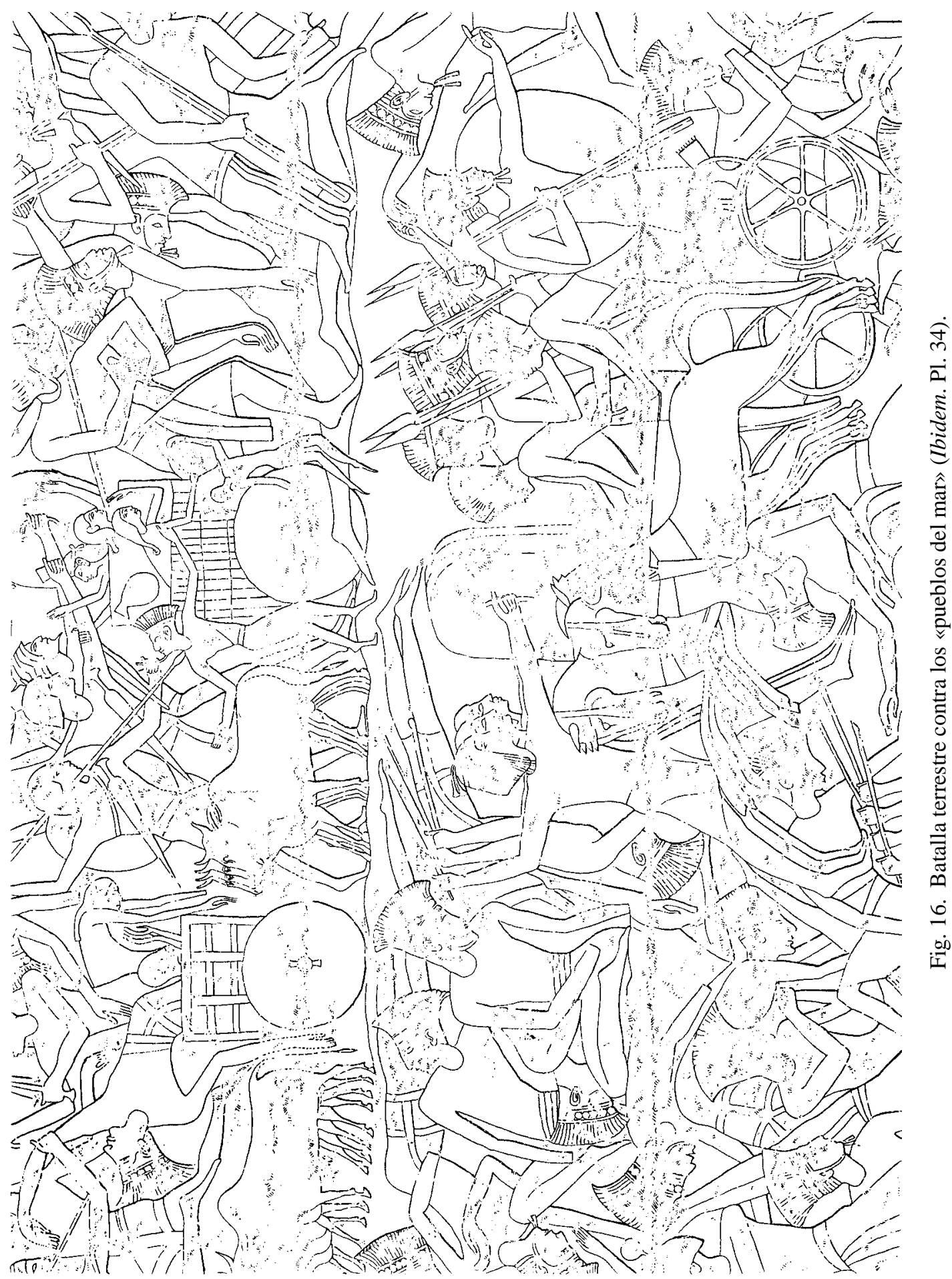
La situación es de clara desventaja para los enemigos de Faraón que caen « under awe at the sight of him, as when Set rages, overthrowing the enemy in front of the sun bark, trampling down the plains and hill-countries, (which are) prostrate, beaten from tail to head before his horses. His heat burns up their bodies like a flame. Hacked up is their flesh to the duration [of eternity]» ${ }^{62}$.

Faraón infringe, según los textos y los relieves, una derrota total a las fuerzas enemigas, deteniendo la marea humana que amenazaba Egipto por tierra.

Pero aún tenía que enfrentarse a otra parte del ejército invasor que trataba de penetrar en barco por el Delta. Las convenciones narrativas de la época hacen que esta batalla naval nos aparezca representada casi simultáneamente en el tiempo (Fig. 17). Probablemente no ocurrió así. La invasión de los «pueblos del mar» no parece estar bien coordinada y con un mando único al frente de una coalición, puesto que no se mencionan los nombres de los jefes. Más bien parece tratarse de intentos sucesivos de penetración por diferentes vías.

En el río, los barcos de Faraón detuvieron el avance de las embarcaciones enemigas bloqueando las bocas del Nilo con barcos de guerra y con barcos mercantes:

«Now the heart of this god, the Lord of the Gods, was prepared, ready to ensnare them like birds. He made my strength to exist, while my plans succeed. My_goes forth, pouring out like a miracle. I organized my frontier in Zahi, prepared before them, (to wit,)the princes, the commanders of the garrisons, and the Mariannu. I caused the Nile mouth to be prepared like a strong wall with warships, galleys, and coasters, [equiped, for they were manned completely from bow to stern with valiant warrios, with their weapons; the militia consisting of every picked man of Egypt, were like lions roaring upon the mountains tops. The chariotry consisted of runners, of picked [picked men], of every good and capable charriotwarrior. Their horses were quivering in every part of their bodies, ready to crush the countries under their hoofs. I was the valiant Montu standing fast at their head, so that they might gaze upon the capturings of my two hands; King of Upper and Lower Egypt: UsermareMeriamon; Son of Re: Ramses III.»63

Los relieves de la pared norte del Gran Templo de Medinet Habu recogen, con un gran lujo de detalles, la más antigua representación de una batalla naval.

Ramses acudió con su ejército de tierra hasta la desembocadura del río Nilo para apoyar a su marina de guerra.

El rey se baja del carro de guerra. Su ayudante de campo sujeta y tranquiliza a los caballos. Ramses Heqa-Iunu, pie en tierra ${ }^{64}$, abre su carcaj, tensa su arco y comienza a disparar flechas sobre los barcos enemigos atrapados en las bocas del Nilo y cerca de la orilla. El

\footnotetext{
62 Ver fig. 2.17. W.F. EdGERTON y J. A. WiLSON, Historical Records of Ramses III. The Texts in Medinet Habu. Volumes I and II, Chicago 1936, p. 38-39. La imagen puede consultarse en EPIGRAPHIC SURVEY, Medinet Habu, Volume I, Earlier Historical Records of Ramses III, Chicago 1930, plate 32-34. Ver también J. H. BREASTED, Ancient Records of Egypt, Volume IV, New York 1962 (1906) \# 73, p. 43.

63 Ver fig. 2.14. W.F. EDGERTON y J. A. WILSON, Historical Records of Ramses III. The Texts in Medinet Habu. Volumes I and II, Chicago 1936, p. 54-55. La imagen puede consultarse en EPIGRAPHIC SURVEY, Medinet Habu, Volume I, Earlier Historical Records of Ramses III, Chicago 1930, plate 46. Ver también J. H. BREASTED, Ancient Records of Egypt, Volume IV, New York 1962 (1906) \# 65, p. 38. Dada la forma en que Ramses III dice que ha atrapado al enemigo y el tipo de embarcaciones que ha utilizado (gabarras o barcos de transporte de carga por río), en mi opinión la batalla naval se dio en las bocas del Nilo. La táctica de bloquear con barcos más pesados y menos operativos también fue utilizada por los persas en la batalla de Salamina (480 a.C.), durante la Segunda Guerra Médica. Ver HERODOTO, Historias. Libro VIII, Biblioteca Clásica Gredos, Madrid 1989, p. 161. Igualmente se puede consultar en N.G.L. HAMMOND, «The battle of Salamis», Journal Hellenic Studies 76, 1956, p. 5, y, más recientemente, J.F. LAZENBY The defence of Greece, Warminster 1993, p. 198.

64 Ver 2.18. Epigraphic Survey. Medinet Habu, Vol. I. Earlier Historical Records of Ramses III, Chicago 1930, Plate 37.
} 


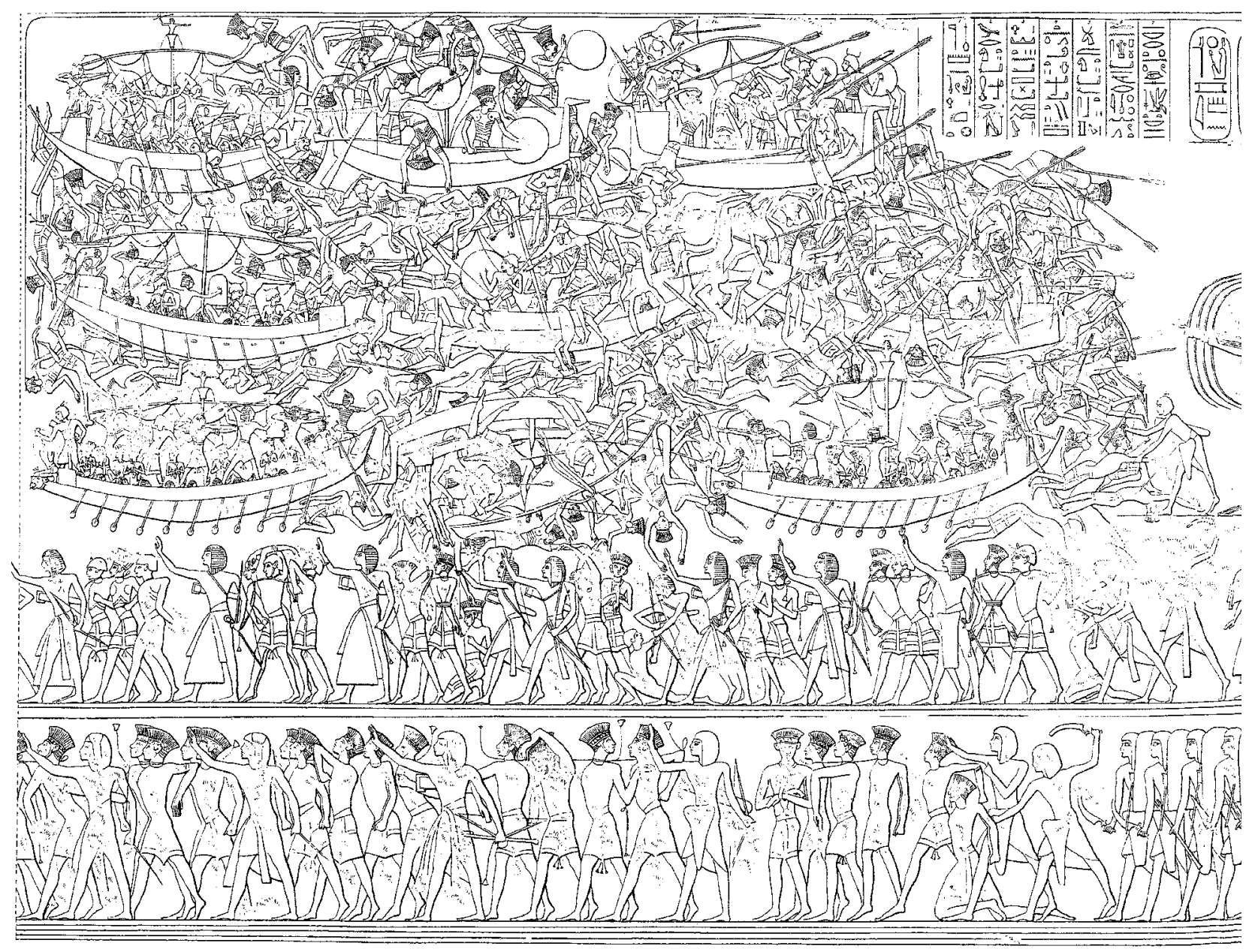

Fig. 17. Batalla naval contra los 


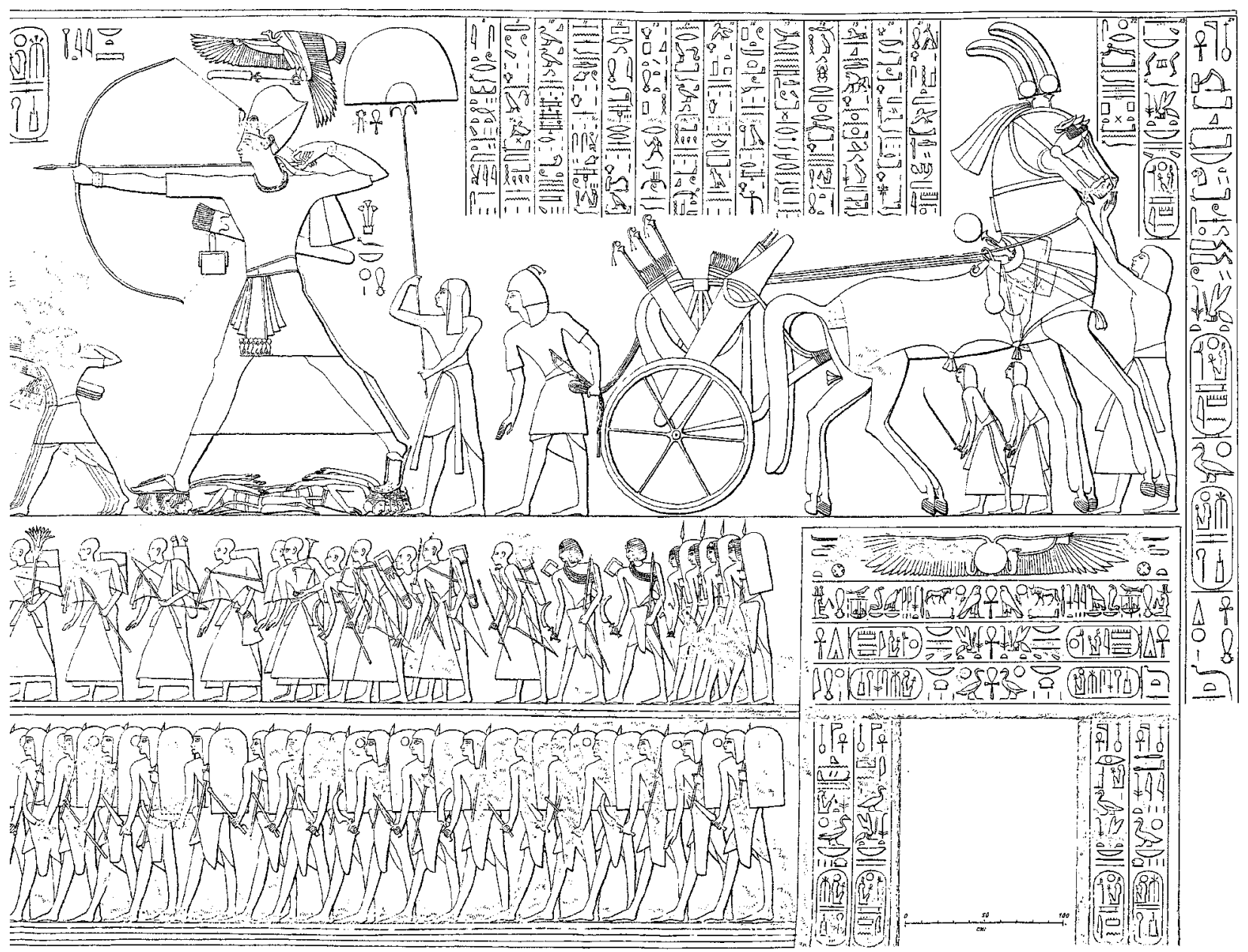

«pueblos del mar» (Ibidem. Pl. 37). 
cuerpo de arqueros que le acompaña secunda al rey y una nube de flechas cae sobre los invasores que vienen por mar.

«I am one who acts urestrainedly, conscious of his strenght, a hero, rescuing his army on the day of the fray.

As for those who reached my frontier, their seed is not, their heart and their soul are finished forever and ever. As for those who came forward together on the sea, the full flame was in front of them [at] the Nile mouths, while a stockade of lances surrounded them on the shore, (so that they were) dragged (ashore), hemmed in, prostrated on the beach, slain, and made into heaps from tail to head. Their ships and their goods were as if fallen into the water...» ${ }^{65}$

Los barcos de Faraón, de poco calado y provistos de un sistema de impulsión mixto, de velas y remos, maniobran con celeridad, y atacan por el río, volcando las naves enemigas, asaeteando a los intrusos en rápidas pasadas junto a sus naves, abordándolas y haciendo prisioneros a los supervivientes. Los barcos de guerra de Faraón son ligeros, la quilla casi plana. Un mástil en el centro del barco sujeta la vela cuadrada, que es recogida durante el combate. Desde la cofa, en lo alto del mástil, un vigía informa de los movimientos de los otros barcos. En el castillo de proa, un grupo de arqueros dispara sus flechas sobre los barcos enemigos. En el castillo de popa se sitúa el timonel que gobierna los movimientos del barco con los grandes remos situados al final de la nave. La amenazadora cabeza de un león enfurecido en la proa, que lleva en sus fauces abiertas la cabeza de un enemigo de Egipto, apoya con su imagen y su magia, el ataque de la marina de guerra de Faraón.

Las tripulaciones de los barcos de Faraón están formadas exclusivamente por remeros y soldados egipcios, que maniobran con habilidad y celeridad frente a los barcos enemigos, identificados con la cabeza de un ánade tanto en la proa como en la popa. Estos últimos, con las velas plegadas y sin utilizar remos, se ven asaeteados primero, tanto desde el agua como desde tierra firme, y abordados después por la marina real, cuyos barcos llevan la destrucción total a la flota enemiga (Fig. 17).

Aquellos que consiguen librarse de los barcos de Faraón y no han muerto ahogados, llegan hasta la orilla y son capturados por la infantería del rey, apostada junto a las orillas del río. Finalmente, los enemigos que han sobrevivido son atados por los codos o esposados por las muñecas. El intento de los Pueblos del Norte de penetrar por el mar es rechazado, y su flota destruida.

Los artesanos de Ramses III en Medinet Habu, han conseguido que esta transcendental batalla naval quede reflejada en un cuadro extraordinariamente vivo, en el que solo aparecen nueve naves: cuatro barcos egipcios y cinco barcos enemigos, en plena lucha.

Después de la batalla ${ }^{66}$, Ramses Heqa-Iunu reune en su castillo ${ }^{67}$ a los príncipes de Egipto, a los visires y a los jefes del ejército. En mitad de un amplio patio se dispone a dirigirse a los congregados. Tras él dos cortesanos portan sendas sombrillas protegiendo al rey. Siete ayudantes llevan las armas y útiles del faraón. Su ayudante de campo sujeta las riendas mientras otros tranquilizan a los caballos aún uncidos al carro de guerra del Rey.

65 Ver fig. 2.14. W.F. EdGERTON y J. A. WILSON, Historical Records of Ramses III. The Texts in Medinet Habu. Volumes I and II, Chicago 1936, p. 53. La imagen puede consultarse en EPIGRAPHIC SURVEY, Medinet Habu, Volume I, Earlier Historical Records of Ramses III, Chicago 1930, plate 46. Ver también J. H. BREASTED, Ancient Records of Egypt, Volume IV, New York 1962 (1906) \# 65, p. 38.

66 Ver 2.19 Epigraphic Survey. Medinet Habu, Vol. I. Earlier Historical Records of Ramses III, Chicago 1930, Plate 42 .

${ }^{67}$ El lugar es descrito como $m^{`} g 3 y r n(y)$ seguido del cartucho real, es decir, el migdol de Ramses Heqa-Iunu. 
Sube a un podio y apoyado sobre un balcón acolchado dirige un discurso triunfal a sus gentes (Fig. 18):

«Spoken by his majesty to the royal princes, the officials, the royal chamberlains, and the charioteers: "See ye the great strength of my father Amon-Re! As for the countries who came form their land in the isles in the midst of the sea, as they were (coming) forward toward Egypt, their hearts relying upon their hands, a net was prepared for them, to ensnare them. They that entered into the Nile mouths were [caught], fallen into the midst of it, pinioned in their places, butchered, and their bodies hacked up. I have caused that you see my strength, wich was in that wich my arm has done, while I was alone. My arrow hit the mark without fail, while my arms and my hand were steadfast. I was like a falcon in the midst of small fowl, for my talon did not fail upon their heads. Amon-Re was on my right and on my left, and the awe of him and the terror of him were in my person. Rejoice ye, for that which I commanded is come to pass, and my counsels and my plans are perfeted. Amon-Re repels my foe and gives to me every land into my grasp» ${ }^{68}$.

El ejército, con sus oficiales en uniforme de parada, desfila ante el Rey con las enseñas de las distintas unidades militares. Los príncipes llevan ante el Rey a los capitanes del ejército enemigo, esposados o con los brazos atados a la espalda por los codos.

Un grupo de soldados procede al recuento de las manos de los enemigos muertos en la batalla, que los escribas registran cuidadosamente. Numerosos jóvenes soldados prisioneros, despojados de sus corazas y sus armas, esperan sentados el interrogatorio de los escribas, que les asignarán un nuevo destino en Egipto.

Ramses Heqa-Iunu, desde su trono, pudo dictar a los escribas el siguiente párrafo de su densa historia ${ }^{69}$ :

«Jái élargi toutes les frontières de Kémet, et j'ai renversé ceux qui les transgressaient depuis leurs (76,7) pays: j'ai détruit les Dénénou (qui venaient) de leurs îles; les Tjékérou et les Pelsétou ont été réduits en cendres, ainsi que les Shardanes (sic!) et les Oushéshou, (qui venaient) de la mer. $(76,8)$ Ils ont éte anéantis, faits prisonniers en une (seule) fois et amenés comme tels en Kémet, (nombreux) comme le(s grains de) sable de la berge $e^{918}$.

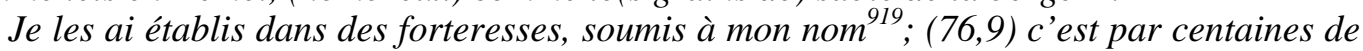
milliers que l'on compte les jeunes gens parmi eux (litt.: leurs jeunes gens sont nombreux comme des centaines de milliers); à tous, j'ai (litt.: je leur ai) alloué annuellement des vêtements et des rations alimentaires provenant des trésors et des enclos à céréales ${ }^{920}{ }$.

Los peleset $^{70}$, tras su derrota, quedaron definitivamente asentados en Palestina ${ }^{71}$. Las fronteras del Norte y el Este quedaron aseguradas con la victoria total de Faraón, que consiguió contener la marea humana de los «Pueblos del Mar»:

\footnotetext{
68 Ver fig. 2.19. W.F. EdGERTON y J. A. WILSON, Historical Records of Ramses III. The Texts in Medinet Habu. Volumes I and II, Chicago 1936, p. 42-43. La imagen puede consultarse en EPIGRAPHIC SURVEY, Medinet Habu, Volume I, Earlier Historical Records of Ramses III, Chicago 1930, plate 42. Ver también J. H. BREASTED, Ancient Records of Egypt, Volume IV, New York 1962 (1906) \# 77, p. 45.

69 Papiro Harris I (B.M. 9999) 76,7 a 76,9. Ver P. GRANDET, Le Papyrus Harris I (BM 9999), Volume I, Le Caire 1994, p. 336.

70 Ver I. FinKELSTEIN «Philistine Chronology: High, Middle, or Low?» en S. GiTIN, A. MAZAR y E. STERN (ed.) Mediterranean Peoples in transition. Thirteenth to Early Centuries BCE, Jerusalem 1998, p. 141.

${ }^{71} \mathrm{La}$ idea, generalmente aceptada, es que los pelsetu conforman el pueblo que en fuentes bíblicas identificamos como los filisteos. No obstante, existen planteamientos distintos que quieren ver un origen persa en los peleset. Ver, por ejemplo, Inmmanuel VeliKovSKy, Peoples of the Sea, New York 1977. Para este debate ver también Leonard H. LESKO «The Wars of Ramses III», Serapis 6, (1981/82) p. 83.
} 


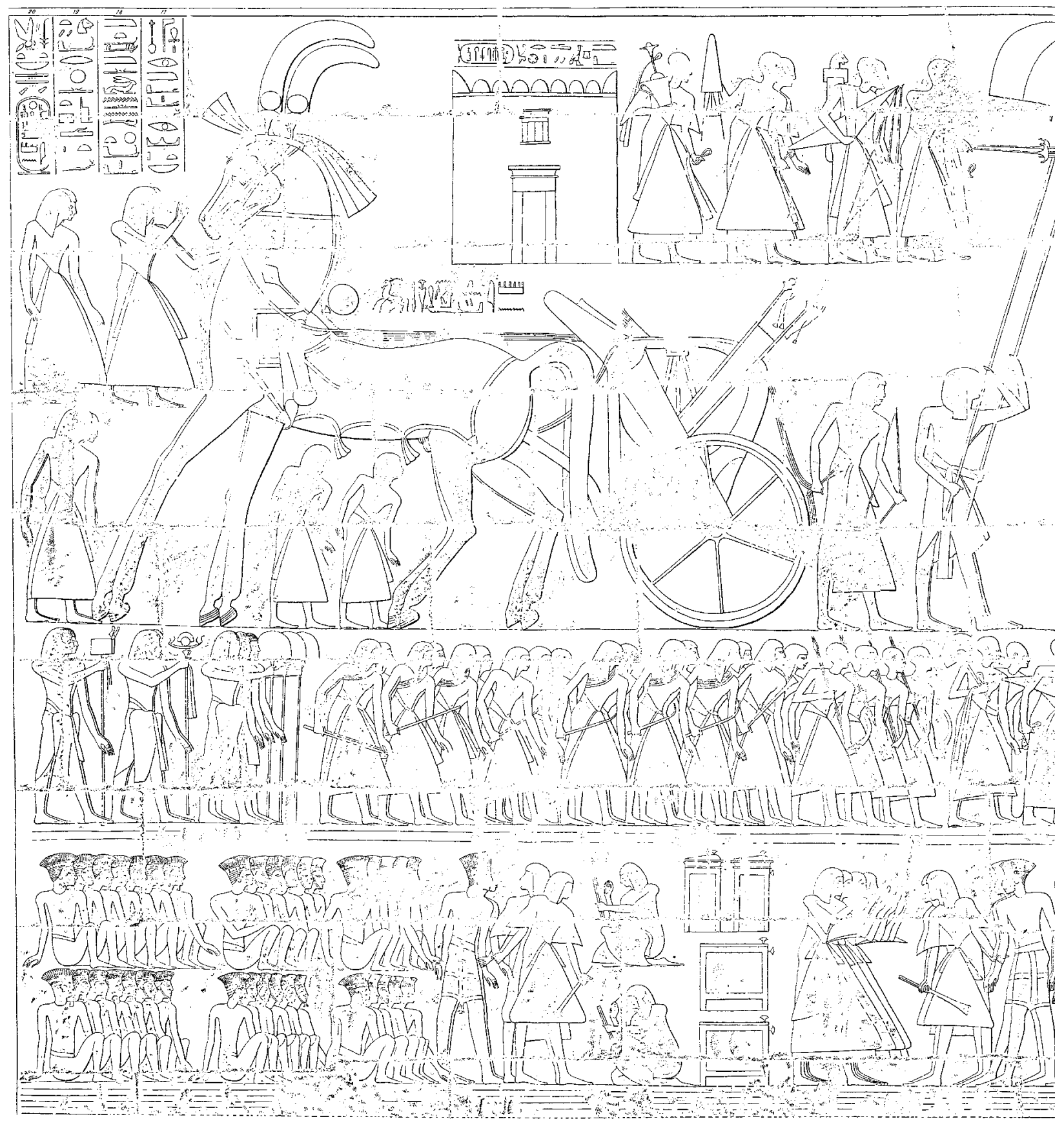

Fig. 18. Ramses III se dirige a su ejército tras la 


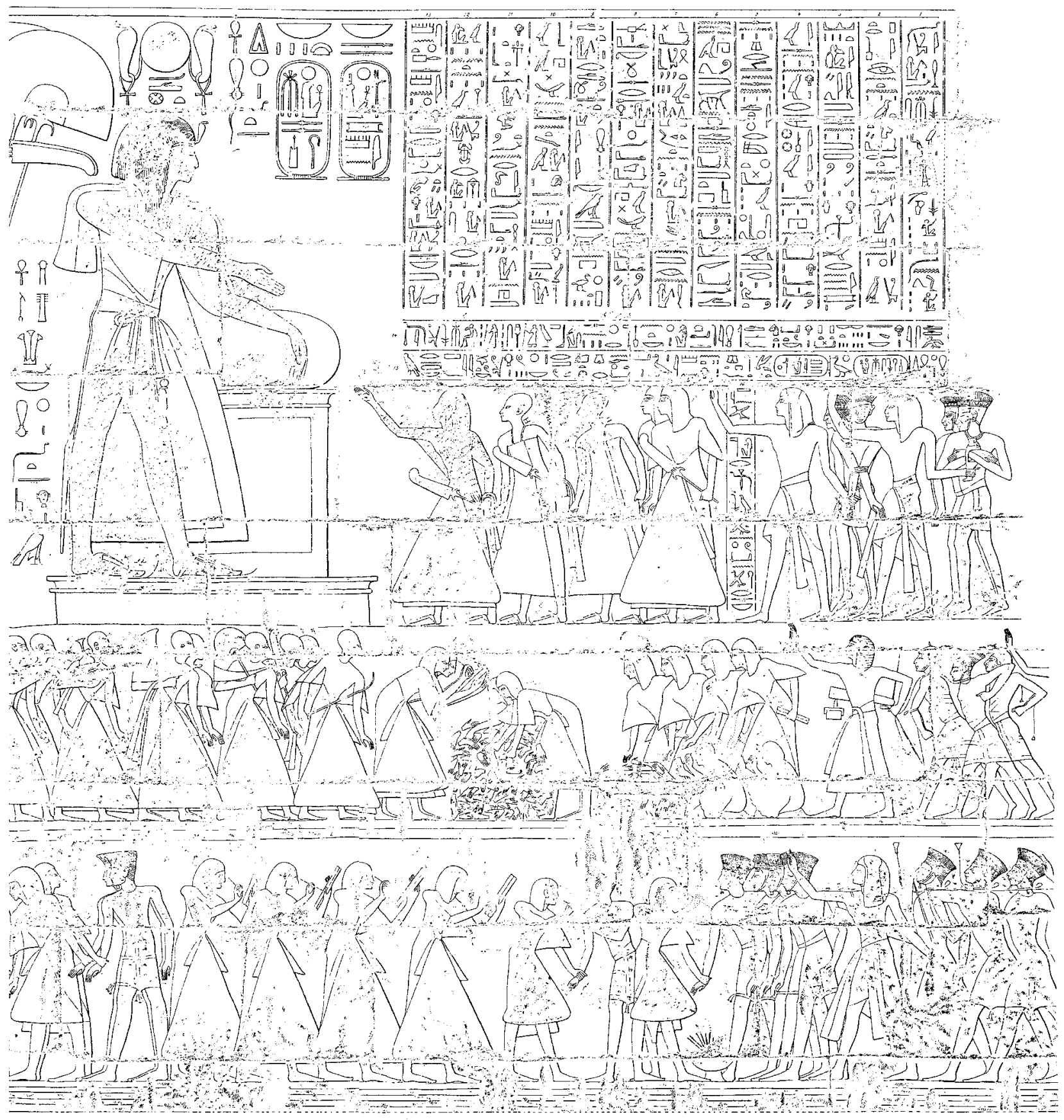

victoria sobre los «pueblos del mar» (Ibidem. Pl. 42). 
«...he has trampled the foreign lands and the islands, his [forces (i)] crossing over [... ...] the Pelest and the Teresh ${ }^{72}$ sailed in the midst of the s]ea [...] in [... ...] his [...]; the King of Upper and Lower Egypt and Lord of the Two Lands: Usimare Meriamun, the Son of Re, [Rame]sses III Heqaon...» 73

No obstante, los restos arqueológicos egipcios en la zona son muy escasos a partir de este reinado.

La situación final en cuanto a la distribución ${ }^{74}$ de las áreas de influencia de Egipto y los recién llegados, así como de las fechas en que ocurrió, sigue siendo objeto de controversia. La continua aparición de nuevos restos arqueológicos y su interpretación inclina, a la mayoría de los investigadores, a confirmar por esta vía, aquello que de una manera tan plástica nos trasladan las fuentes egipcias.

Un testimonio de la ocupación egipcia en esta época son las llamadas «residencia del gobernador». Dos poderosas fortalezas, la de Megido y la de Beth-Shean guardan testimonios de esta presencia. La de Megido estaba gobernada por Dyehutymose, Jefe de Tropa y Jefe de los Países Extranjeros, según los restos arqueológicos encontrados ${ }^{75}$. Pero la mejor conocida es la de la ciudad de Beth-Shean, situada también sobre una colina fortificada que permitía controlar el valle del Jordán. Conocemos ${ }^{76}$ incluso el nombre del gobernador que habitaba esta residencia: Ramses User-Jepesh, hijo del gobernador de Megido. Lo cierto es que las inscripciones más tardías encontradas, así como las estatuas y relieves ${ }^{77}$, pertenecen al reinado de Ramses III, por lo que es posible suponer que esta ciudad quedó finalmente en el territorio ocupado por los «Pueblos del Mar».

Si bien Ramses III parece que consiguió derrotar a los «Pueblos del Mar» en el año 8 de su reinado, y asentarlos en fortalezas que podríamos llamar «fronterizas» en ese momento, sus sucesores tuvieron dificultad para contener nuevas oleadas de estos invasores, que acabaron con el control egipcio en el sur de Canaan ${ }^{78}$, destruyendo sus fortalezas en la segunda mitad del siglo XII a.C.

El dramático relato ${ }^{79}$ del viaje a Biblos de Unamón, un sacerdote egipcio del dios Amón, que trata de conseguir madera para la construcción de una nueva barca para el dios, sitúa la

72 En los teresh o tursha cree reconocer Schulten el origen etimológico de la palabra Tartessos. Ver S. CELESTINO «Una cultura llena de enigmas» La Aventura de la Historia 27 Marzo 2000, p. 67. Si esta interpretación fuese correcta tendríamos que admitir la posibilidad de que el origen de la civilización de Tartessos en la Península Ibérica pudo tener relación con las guerras del faraón Ramses III. Ver también B. SALVA, «¿Pueblos del Mar en la cultura Talayótica? Un estado de la cuestión». Gerión, n. ${ }^{\circ}$ 17, 1999, pp. 79-104.

73 Ver A.J. PEDEN en Egyptian historical inscriptions of the twentieh dynasty. Jonsered 1994, p. 63-68.

Estela retórica de Ramses III en Deir el-Medina. Ver N.K. SANDARS The Sea Peoples. Warriors of the Ancient Mediterranean 1250-1150 BC. London, 1978, p. 164. Es la única donde se mencionan a los peleset como pueblos que vienen del mar.

${ }^{74}$ Ver mapa en M. BIETAK «Zur Landnahme Palästinas durch die Seevölker und zum Ende der ägyptischen Provinz Kana’an» en Mitteilungen des Deutschen Archäologischen Instituts Abteilung Kairo, Band 47, 1991,p.48.

75 Un cálamo de marfil. Ver K.A. KITCHEN Ramesside Inscriptions Historical and Biographical, Oxford 1983, 255-16.

76 Ver C. VANDERSLEYen, L'Égypte et la Vallée du Nil. Tome II: De la fin de l'Ancien Empire à la fin du Nouvel Empire, Paris 1995, p. 604, y K.A. KITCHEN Ramesside Inscriptions Historical and Biographical, Oxford 1983, 253-15.

77 En la campaña de excavación de 1990-1991 en Beth Shean, llevada a cabo por el Instituto de Arqueología de la Universidad Hebrea de Jerusalen, se encontró un relieve de un hombre sentado, cuya datación más probable es el reinado de Ramses III. Ver Deborah Sweeney, «The Man on the Folding Chair: An Egyptian Relief from Beth Shean», Israel Exploration Journal, Vol. 48, 1998, p. 38-53.De excavaciones anteriores tenemos la magnífica estatua de basalto conservada en el Museo Arqueológico de Jerusalén. Ver B. PORTER y R. Moss, Oxford, VII, 1952, Topographical Bibliography of Ancient Egyptian Hierogryphic text, Reliefs and Paintings, p. 379

78 Ver I. FinKELSTEIN «Philistine Chronology: High, Middle, or Low?» en S. Gitin, A. MAZAR y E. STERN (ed.) Mediterranean Peoples in transition. Thirteenth to Early Centuries BCE, Jerusalem 1998, p. 143.

79 Ver J.M. Galan Cuatro Viajes en la Literatura del Antiguo Egipto, Madrid 1998, pp. 179-237. 
acción al final de la dinastía XX (ca. 1075 a.C.). En el relato se nos evidencia hasta qué punto había decaído la autoridad de Egipto en la zona levantina.

Igualmente, las relaciones ${ }^{80}$ comerciales entre Egipto y sus socios comerciales de Chipre y el mundo Egeo se deterioraron extraordinariamente, según ha podido constatarse por evidencias arqueológicas ${ }^{81}$. Esta interrupción se produjo en ambos sentidos dada la crisis final del mundo micénico y la entrada de Grecia en la «Edad Oscura» 82 .

\subsection{La gran batalla contra los pueblos del desierto occidental.}

Pero el ejército de Faraón habría de librar aún otra gran batalla contra la confederación de pueblos del desierto occidental. El problema con los Pueblos del Oeste distaba mucho de haberse resuelto definitivamente. Si bien Ramses III había conjurado el peligro de las invasiones libias en el año 5, que amenazaban directamente a Menfis, corazón administrativo de Egipto, la amenaza no había desaparecido totalmente. Seis años más tarde, en el año 11 de su reinado, los mesheuesh había conseguido organizar una federación de tribus libias, esta vez bien estructurada, para destruir las defensas de Faraón en la frontera occidental.

Estaban dirigidos por un lider llamado Mashar (m3̌šr) hijo de Kapur $(k 3 p w r)^{83}$, según podemos ver en las inscripciones de Medinet Habu ${ }^{84}$.

El enfrentamiento vino precedido por la invasión de Tchehenu, un pueblo del desierto occidental fronterizo con Egipto, por parte de los meshuesh:

«The Meshwesh (chief) [previously, before he was seen], was coming, having [moved away] all together, his land with him, having fallen upon the Tehenu, who were made ashes. Desvastated and desolated were their towns, non-existent was their seed.» ${ }^{85}$

Los meshuesh, además, tuvieron que atravesar la tierra de los tchehenu para llegar al Valle del Nilo, por lo que estos últimos acabaron siendo arrastrados también a la guerra ${ }^{86}$.

Para la ubicación temporal de la batalla contamos con dos fechas entre las cuales hay unos seis meses de diferencia. La primera fecha, en el llamado Poema de la Segunda Guerra Libia $^{87}$, es el día 7 del mes 6 (segundo mes de la segunda estación) del año 11, que podría corresponder al inicio de las hostilidades. La segunda fecha parece referirse al día de la bata-

\footnotetext{
80 Ver J. VerCOUTTER, Essai sur les relations entre Egyptiens et Préhellènes, Paris 1953, p. 95.

81 Ver J.M. WEINSTEIN, «Egyptian relations with the Eastern Mediterranean World at the End of the Second Millennium BCE» en S. Gitin, A. MAZAR y E. STERn (ed.) Mediterranean Peoples in transition. Thirteenth to Early Centuries BCE, Jerusalem 1998, p. 188.

82 Ver V.R. d'A. Desborough, The last Myceneans and their successors. An archaeological survey. 1200-1000 B.C., Oxford, 1964.

83 Ver M. J. LOPEZ GRANDE «Los vecinos occidentales del Antiguo Egipto. Datos anteriores a la proclamación de Sheshonq I». Culturas del Valle del Nilo I; su historia, relaciones externas e investigación española. Universidad Autónoma de Madrid (e.p.).

84 Ver fig. 2.21. W.F. EdGeRTON y J. A. WILSON, Historical Records of Ramses III. The Texts in Medinet Habu. Volumes I and II, Chicago 1936, p. 66. La imagen puede consultarse en EPIGRAPHIC SURVEY, Medinet Habu, VolumeII, Later Historical Records of Ramses III, Chicago 1932, plate 75.

85 Ver fig. 2.20. W.F. EDGERTON y J. A. WILSON, Historical Records of Ramses III. The Texts in Medinet Habu. Volumes I and II, Chicago 1936, p. 76. La imagen puede consultarse en EPIGRAPHIC SURVEY, Medinet Habu, Volume II, Later Historical Records of Ramses III, Chicago 1932, plate 80-83. Ver también J. H. BREASTED, Ancient Records of Egypt, Volume IV, New York 1962 (1906) \# 87, p. 52.

${ }^{86}$ Los tchehenu eran un pueblo frontera para Egipto, uno de los nueve arcos, y en las fuentes egipcias ramésidas nunca confundieron los tchemehu y los tchehenu.

87 Ver J. H. BREASTED, Ancient Records of Egypt, Volume IV, New York 1962 (1906), \# 94, p. 56.
} 
lla definitiva. La fecha está incorporada al texto que acompaña los relieves ilustrativos de la batalla.

La batalla definitiva parece ser que ocurrió entre el día 10 y el día 20 del mes 12 (cuarto mes de la tercera estación) del año 11 de Ramses III ${ }^{88}$; Se produjo junto a una fortaleza llamado Hatsho (ht št), defendida por soldados egipcios. Un ataque o asedio a dicha fortaleza pudo desencadenar la batalla final, al acudir Faraón en ayuda de esta guarnición.

Según las representaciones y los textos, Ramses III luchó directamente contra sus enemi$\operatorname{gos}^{89}$. Los libios, vencidos, fueron perseguidos por el ejército egipcio a lo largo del desierto desde Hut-shay, el Castilllo de Arena, hasta Up-ta ${ }^{90}$, durante más de 84 kilómetros (8 itrw) ${ }^{91}$.

En la batalla, además, Ramses III capturó a Mashar, el jefe enemigo. Tras la batalla se desarrollan escenas dramáticas, como la de Kapur, el padre del jefe de los guerreros aliados contra Egipto, pidiendo clemencia.

El ejército de Ramses III causó 2.175 bajas al enemigo, además de tomar 2.052 prisioneros. No conocemos las bajas del ejército egipcio. Los escribas hacen un detallado informe de las bajas, de los cautivos y del botín de guerra capturado al enemigo:

«Total of hands: 2.175

The plunder wich the mighty sword of Pharaoh, L.P.H., carried off from the fallen ones of Meshwesh:

chief of the Meshwesh great ones of the enemy

Meshwesh

youths

boys

Total

their wives

maidens

girls
1 man

$3[+2=5]$ men

5 men

$1.100[+100=1.200]$ men

152

131

\subsection{4}

342 women

65

151

The total which the mighty sword of Pharaoh, L.P.H., carried off as captives: various individuals

Meshwesh whom his majesty slew in their places: 2.175 men. Their goods, their herds, $129+$; swords of 4 cubits: 116; swords of 3 cubits: 123; bows: 603; charriots: 92 [ quivers: 2.310; [ charriot-poles]: 92; spans of the Meshwesh \{and asses\}: 184» ${ }^{92}$.

88 Ver J. H. BREASTED, Ancient Records of Egypt, Volume IV, New York 1962 (1906), \# 105, p. 61. El día no se puede leer bien, pero es mayor que diez y menor que veinte.

89 Ver J. H. BREASTED, Ancient Records of Egypt, Volume IV, New York 1962 (1906), \# 102, p. 59.

90 Up ta es una región a la altura de Napata. Ver Op. cit. de Vandersleyen, C. en Proceedings of the Sevetnth International Congress of Egyptologists, Leuven (1998), p. 1202.

91 Ver P. GRANDET, Le Papyrus Harris I (BM 9999), Le Caire 1994, Vol. II, 248.

92 Ver fig. 2.21. W.F. EDGERTON y J. A. WILSON, Historical Records of Ramses III. The Texts in Medinet Habu. Volumes I and II, Chicago 1936, p. 65-66. La imagen puede consultarse en EPIGRAPHIC SURVEY, Medinet Habu, Volu- 
Además del rey, en la batalla tuvo un lugar destacado el príncipe heredero, que ejerce la función de Comandante en Jefe del Ejército, como también ocurrió en las guerras de Sethnajt, en las que participó su hijo, el futuro Ramses III:

"[The King himself says to the Crown Pri]nce Royal Scribe, Chief Commander of the Army, and Royal Son. "Say to the fallen one of Meshwesh: "Behold [now], thy name is desolated forever and ever. Thy mouth ceases to boast at the memory of Egypt. It was the strenght of my father, the Lord of the Gods, that gave to me his dread in orden to destroy thee" "93

Finalmente el rey informa al dios Amón de la derrota de los meshuesh:

«As for the Meshweshite, I overthrew his power, I annihilated his soul forever, through the strength of thy land, slaying them. (Thus) the things which thou hast promised are come to pass.» ${ }^{94}$

Tras el balance de la batalla, Ramses III informa acerca del destino final de los que han sobrevivido:

«J'ai abattu la (peuplade des) (77,3) Meshwesh les Libou, les Isébétou, les Qeyqéshou, les Sheytépou (?), les Hésou et les Béqénou ${ }^{926}$ : ayant éte abattus dans leur (propre) sang et réduits en une pile de cadavres, jái fait en sorte qu'ils cessent (désormais) $(77,4)$ d'errer sur la frontiére de Kémet ${ }^{927}$.

J'ai ramené (en Égypte ceux) que j'avais épargnés et (n')avais (que) blessés, en tant que prisonniers innombrables, liés (par les bras), comme des oiseaux ${ }^{i}$ (para les ailes), à l'avant de mes chevaux. Leurs femmes et leurs enfants étaient des dizaines de milliers, $(77,5)$ et leurs (têtes de) bétail, de toute sorte, des centaines de milliers ${ }^{928}$. J'ai établi leurs meilleurs soldats (HAwtyw) dans des forteresses portant mon nom. (Aux autres) j'ai (litt.: je leur ai) donné de nombreux chefs de troupes de tribu, après qu'ils eussent été marqués (au fer rouge) et transformés (ainsi) en (77,6) esclaves, estampillés à (mon) nom. Leurs femme(s) et leurs enfant(s) ont été traités de même; et j'ai conduit leur bétail au domaine d'Amon, en faveur duquel il a été organisé en troupeaux pour l'éternité ${ }^{929} .{ }^{95}$

Los mejores soldados, de entre los prisioneros, fueron incorporados al ejército egipcio y situados en las fortalezas que formaban parte del sistema defensivo egipcio. El resto fue organizado en grupos, a los que se asignó un jefe de entre ellos. En cualquier caso fueron marcados con el nombre de Ramses III, estampillándoles sobre la piel el nombre del rey con metal al rojo vivo. Estos grupos de hombres, junto con sus mujeres, hijos y ganado fueron adscritos a las explotaciones de los Dominios de Amón.

me II, Later Historical Records of Ramses III, Chicago 1932, plate 75. Ver también J. H. BREASTED, Ancient Records of Egypt, Volume IV, New York 1962 (1906) \# 111, p. 66.

93 Ver fig. 2.22. W.F. EdGeRTON y J. A. WILSON, Historical Records of Ramses III. The Texts in Medinet Habu. Volumes I and II, Chicago 1936, p. 63. La imagen puede consultarse en EPIGRAPHIC SURVEY, Medinet Habu, Volume II, Later Historical Records of Ramses III, Chicago 1932, plate 74. Ver también J. H. BREASTED, Ancient Records of Egypt, Volume IV, New York 1962 (1906) \# 109, p. 64.

94 Ver fig. 2.23. W.F. EdGerTon y J. A. WILSON, Historical Records of Ramses III. The Texts in Medinet Habu. Volumes I and II, Chicago 1936, p. 70. La imagen puede consultarse en EPIGRAPHIC SURVEY, Medinet Habu, Volume II, Later Historical Records of Ramses III, Chicago 1932, plate 78. Ver también J. H. BREASTED, Ancient Records of Egypt, Volume IV, New York 1962 (1906) \# 113, p. 67.

95 Ver P. GRANDET, Le Papyrus Harris I (BM 9999), Volume I, Le Caire 1994, p. 337. 
El relato de las batallas quedó grabado sobre los muros de Medinet Habu, a fin de que las victorias se perpetuasen mágicamente para el resto de los tiempos. Habían sido dos duros episodios de una guerra cruel, quizás por la supervivencia de un pueblo.

En cualquier caso Ramses III debía ser consciente de que el problema no se terminaba ${ }^{96}$ con aquellas luchas y mandó fortificar las principales ciudades de la orilla oeste. Alrededor del templo de Hermópolis ${ }^{97}$ hizo construir un muro de 15 metros de altura que Ramses III dice que era para mantener a distancia a los extranjeros de Tchehenu:

«J'ai ceint le domaine de Thot d'une enceinte ${ }^{786}$ solide, de 20 rangées (?) (de briques) en fondation et d'une hauteur de 30 coudées, munie d'entrées monumentales (?), de tours de flanquement (?) et de bastions sur tout son pourtour, $(58,6)$ et dont les montants de porte et les linteaux sont en pierre d'Âyn, munis de portes en pin plaquées de cuivre, afin de tenir à l'écart les étrangers du Téhénou, qui avaient l'habitude de fouler leur frontière depuis (le temps) jadis $^{787} .{ }^{98}$

Asimismo fortifica los templos de Abydos y Assiut. Posiblemente, la imponente muralla que rodeaba los templos de Dyeme ${ }^{99}$ no era ajena a esta permanente amenaza del desierto occidental.

\subsection{Las otras campañas}

\subsubsection{Operaciones en Nubia}

$\mathrm{Si}$, como hemos podido constatar en las demás escenas, existe un orden cronológico en estas representaciones de Medinet Habu, las guerras ${ }^{100}$ contra los nubios son anteriores al año 5. No obstante las guerras contra los pueblos del sur, no están fechadas, ni tenemos datos geográficos, cifras de bajas o nombres de los jefes enemigos vencidos, por lo que más bien parece tratarse de operaciones de castigo contra poblaciones nubias, muy al sur, sobre las que los egipcios ejercían algún tipo de dominio ${ }^{101}$ (Fig. 19).

Los egipcios tenían tropas estacionadas en la fortaleza de Buhén. Al frente de la guarnición se encontraba el Jefe de la tropa de Kush. Era una fortaleza estratégicamente situada para controlar el territorio nubio. Se ubicó junto a la segunda catarata, a la altura del actual Uadi Halfa, en un punto equidistante de la primera y de la tercera catarata. Por tanto, desde aquí dominaban la Baja Nubia (Uauat) y la Alta Nubia (Kush).

Administrando el territorio en nombre de Faraón se encontraba un alto cargo; el Virrey de Kush, en el reinado de Ramses III, Hori hijo de Kamâ, que ostentaba el título de Jefe de los Países del Sur, a quién sucedió su hijo Hori desde el año 5 hasta el reinado de Ramses

\footnotetext{
${ }^{96} \mathrm{La}$ ausencia de referencias o noticias relativas a los oasis podría estar indicándonos que los libu y los mesheuesh habrían cortado las rutas de comunicación con el Valle o, incluso, haber ocupado ellos mismos los oasis. Ver C. VANDERSLEYEN, L'Égypte et la Vallée du Nil. Tome II: De la fin de l'Ancien Empire à la fin du Nouvel Empire, Paris 1995 p. 606. El Papiro Turín, cat. 2074, revela ya la presencia de los mesheuesh en Tebas durante el reinado de Ramses IX.

97 Este templo está situado en la actual ciudad de el-Ashmunein, a unos $200 \mathrm{Kms}$. al sur del Fayum.

98 Ver P. GRANDET, Le Papyrus Harris I (BM 9999), Volume I, Le Caire 1994, p. 305-306.

99 El conjunto hoy conocido como Medinet Habu.

100 En opinión de A.H. Gardiner, las escenas de las batallas en Nubia parecen simples convenciones tomadas de representaciones anteriores. Ver A. H. GARDINER Egypt of the Pharaohs, Oxford, 1961, p. 282. Ver también L. H. LESKO «The Wars of Ramses III», Serapis 6, p. 83.

101 Ver J. H. BREASTED, Ancient Records of Egypt, Volume IV, New York 1962 (1906), \# 136, p. 80. Están reflejadas en la pared occidental del muro exterior del templo de Medinet Habu.
} 


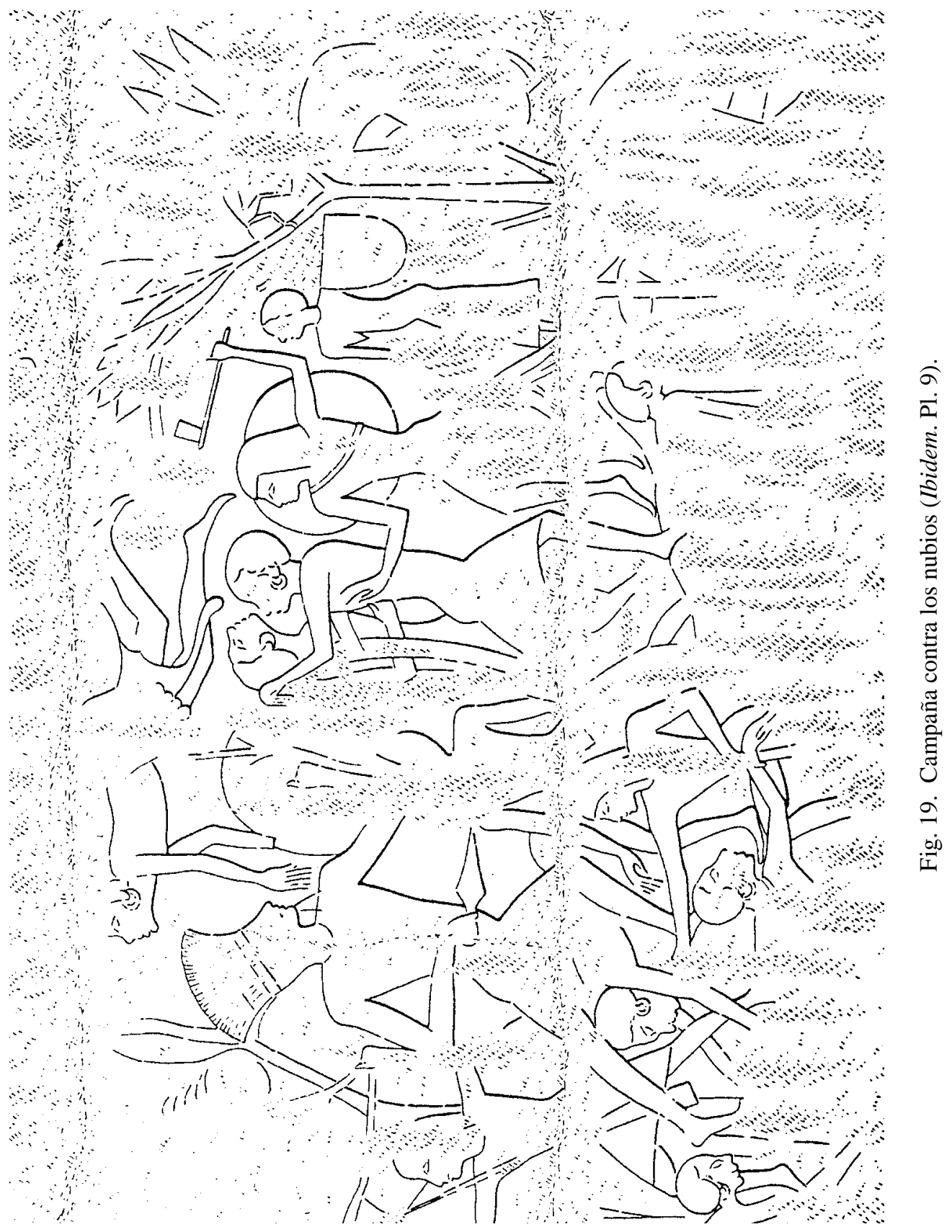


IV $^{102}$. A las órdenes del Jefe de los Países del Sur estaba el Gobernador de Uauat, que tenía su residencia en Aniba,y el Gobernador de Kush, que tenía su residencia en Amara, muy cerca de Soleb, y a unos $150 \mathrm{Kms}$. al sur de la actual frontera entre Egipto y Sudán.

La incursión debió realizarse muy al sur y sobre los poblados. Así parece acreditarlo el hecho de que la acción se desarrolla en un lugar frondoso, entre árboles de tronco corto y hojas enormes.

En una estela, situada en el Santuario de Meretseger, se citan, en relación con estas campañas, dos pueblos nubios: Tirawayu e Irem. Este último es situado en una zona nubia muy al sur, en el Kush ${ }^{103}$.

Las representaciones parietales de Medinet Habu nos muestran el ataque del ejército de carros egipcio, al frente del cual está el rey disparando su arco desde el carro en marcha.

La acción de los arqueros del ejército de carros ha causado estragos. Los soldados nubios, armados con machetes y escudos huyen tratando de proteger a sus mujeres y sus hijos. Los soldados peleset degüellan a los nubios. Los soldados egipcios, hacha en mano, arrancan a las mujeres de los brazos de los hombres de la tribu ${ }^{104}$.

La siguiente representación nos muestra el regreso triunfal de Ramses III con un numeroso grupo de cautivos nubios, que podría ser el objeto último de la incursión ${ }^{105}$.

\subsubsection{Otras operaciones militares}

Entre las guerras de Ramses III, el Papiro Harris hace referencia a una campaña contra los beduinos saru, cuya fecha nos es desconocida. El texto dice así:

«Jái réduit en poussière les Sârou, de la tribu $(76,10)$ des Shasou. J'ai dépouillé leurs tentes (ou: leurs campements?) de leurs gens, de leurs biens et de leurs (têtes de) bétail semblablement, sans limites. Ayant été liés (par les bras) et amenés prisonniers comme butin de Kémet, $(76,11)$ je les ai donnés à (chacun des membres de) l'Ennéade, pour être (litt.: en tant qu') esclaves de (litt.: pour) son (litt.: leur) domaine ${ }^{922}{ }^{106}$.

Además, en los muros de Medinet Habu encontramos referencias a operaciones militares, sin datar, contra los pueblos del desierto oriental.

Esta pudo ser también una expedición de castigo, puesto que la frontera oriental se encontraba protegida por «el Camino de Horus», un fuerte dispositivo fronterizo que ya desde el Imperio Antiguo, defendía a Egipto de las invasiones asiáticas por tierra.

Muy cerca de la desembocadura del brazo pelusiaco, dos grandes lagunas saladas, que el Nilo había dejado en tierra egipcia en su proceso de conquista de espacio al mar, definían y condicionaban el paso entre Asia y Africa. Las lagunas al norte y las dunas al sur dejaban como único paso el camino entre ambas. Allí se encontraba el Jétem de Tcharu ${ }^{107}$, un puesto fronterizo que además servía de base para las operaciones bélicas del ejército egipcio en la zona sirio-palestina. Tcharu tenía puestos de control del ejército egipcio donde se gestionaba el movimiento de ex-

102 Ver C. VANDERSLEYen, L'Égypte et la Vallée du Nil. Tome II: De la fin de l'Ancien Empire à la fin du Nouvel Empire, Paris 1995 p. 606.

103 Ver la llamada «Estela Retórica» en A.J. PEDEN en Egyptian historical inscriptions of the twentieh dynasty. Jonsered 1994, p. 63-68. Para el Santuario ver J. TRELLO, «Meretseger; la que ama el silencio», Revista de Arqueología, n. ${ }^{\circ}$ 232, Agosto 2000, pp. 34-45.

104 Ver 2.6. Epigraphic Survey. Medinet Habu, Vol. I. Earlier Historical Records of Ramses III, Chicago 1930, Plate 9.

105 Ver 2.8. Epigraphic Survey. Medinet Habu, Vol. I. Earlier Historical Records of Ramses III, Chicago 1930, Plate 10.

106 Ver P. GRANDET, Le Papyrus Harris I (BM 9999), Volume I, Le Caire 1994, p. 337.

107 Tcharu se enontraba en la actual Tell Héboua que, desde 1981, está siendo excavada sistemáticamente por Mohamed Abd el-Maksoud. Ver Dominique Valbelle y Mohamed Abd el-Maksoud, «La Marche du Nord-Est», Les Dossiers d'Archeologie 213, Mayo 1996, p. 60. 
tranjeros. También había almacenes con grandes silos para soportar el abastecimiento de las campañas de Asia. La mejor defensa de esta zona fronteriza no eran los altos muros panelados de las fortalezas egipcias sino algo mucho más original: un canal infectado de cocodrilos ${ }^{108}$.

Desde Tchejaru hasta Gaza existían numerosos puntos fortificados que protegían la ruta entre Asia y Africa por el litoral mediterráneo.

Por otra parte, la ruta del Uadi Tumilat se había convertido desde el Imperio Antiguo, o quizás mucho antes, en «el cordón umbilical de los Beduinos». Era un lugar de paso, y durante la ocupación de los hyksos había estado habitado.

Aproximadamente en la mitad de la ruta, a unos $30 \mathrm{Km}$. de los lagos orientales, se encontraba una fortificación ${ }^{109}$ que era clave para controlar el paso de los beduinos, dentro del sistema de fortificaciones que defendían este paso. Aquí estaba el cuartel general de las patrullas que, con regularidad, realizaban tareas de inspección en el Sinaí. Un templo, dedicado a «Atum, señor de Tcheku»» durante la dinastía precedente, servía de residencia al dios protector del lugar. Evidentemente la zona de Tcheku estaba bajo la fuerte influencia de los dioses heliopolitanos. A unos $30 \mathrm{Kms}$. al oeste de esta fortificación estaba Per-Sopdu ${ }^{110}$, «la gran muralla de Egipto que repele a los bandidos del desierto». Sopdu, el dios halcón «Señor del Este», velaba por los egipcios en esta puerta del desierto oriental. En el otro extremo, a unos $15 \mathrm{kms}$. al oeste del lago Timsah, se encontraba Per-Atum, «la casa de Atum» ${ }^{11}$. Esta era, por tanto, una zona de paso muy bien protegida.

Las guerras en territorio sirio ${ }^{112}$ tampoco están datadas en los textos conservados, si bien se considera que estas pudieron producirse en un momento próximo y posterior al año 11 de Ramses III $^{113}$. Los relieves de Medinet Habu nos describen la toma de, al menos, cinco ciudades fortificadas. Se ha especulado sobre la posibilidad de que se tratara de una mera repetición de las campañas de otros faraones y que esta representación no tuviera una base histórica real. No obstante, no podemos descartar que, al igual que el caso de Nubia, se tratara de una campaña para asegurar las fronteras del nordeste, o expediciones punitivas contadas como campañas ${ }^{114}$.

En la primera fortaleza atacada, Ramses III ha bajado de su carro de guerra y pie en tierra dispara su arco contra el enemigo. La fortaleza está fuertemente protegida con cuatro líneas de almenas, en medio de las cuales hay una torre sobre la cual ondea una bandera triangular ${ }^{115}$. Parece ser una ciudad amorita de la cual hemos perdido el nombre en la inscripción.

108 Una representación de este canal infectado de cocodrilos está grabada en el muro norte de la Sala Hipóstila del Templo de Amón en Karnak. Esta representación fue ordenada por Sethy I para conmemorar la campaña bélica que efectuó en Siria en el año 2 de su reinado. Arqueólogos egipcios adscritos a la zona de inspección del norte del Sinaí han descubierto esqueletos de cocodrilos en Tell Moufariq, un lugar relativamente próximo, al noreste de Tell Héboua, lo que confirma la existencia de estos animales en la zona. Desde aquí partió Thutmose III para su primera campaña en Asia.

109 El lugar es conocido actualmente como Tell er-Retabeh.

110 Actualmente a este lugar se le denomina Saft el-Henneh.

111 Per-Atum se convirtió en Pithom. Nekau monumentalizó la ciudad con esculturas y grandes construcciones, muchas veces realizadas con elementos reutilizados de las construcciones ramésidas. Es probable que un jefe árabe, llamado Gashmu, administrara la región en el siglo V a.C., durante la dominación persa. Este jefe árabe dio su nombre a la zona que es conocida como «Geshem», llamada Goshen en la Biblia. Actualmente el lugar se denomina Tell el-Masjuta. Ver Les Dossiers d'Archeologie 213, Mayo 1996.

112 Hay grupos étnicos y nombres geográficos que no pueden ser asignados con total seguridad. Ver B. CIFOLA «The Terminology of Ramses III's Historical Records With a Formal Analysis of the War Scenes», Orientalia 60, 1991, p. 9-57.

113 Ver J. H. BREASTED, Ancient Records of Egypt, Volume IV, New York 1962 (1906), \# 132, p. 78. Hay autores que sostienen se trata de una campaña, probablemente ficticia e idealizada, de la actividad ritualizada del faraón. Ver N.K. SANDARS The Sea Peoples. Warriors of the Ancient Mediterranean 1250-1150 BC. London, 1978, p. 137. En opinión de Gardiner estos relieves son un anacronismo y pueden haber sido copiados de representaciones originales del reinado de Ramses II. Ver Alan H. GARDINER Egypt of the Pharaohs, Oxford, 1961, p. 288. Ver también Leonard H. LESKO «The Wars of Ramses III», Serapis 6, (1981/82), p. 84.

114 Esta es la forma en que lo vemos reflejado en el caso de Thutmose III en relación con la 9 ${ }^{\mathrm{a}}, 10^{\mathrm{a}}, 14^{\mathrm{a}}$ y $17^{\mathrm{a}}$. Ver J. VANDIER, Historia de Egipto, Buenos Aires 1977.

115 Ver J. H. BREASTED, Ancient Records of Egypt, Volume IV, New York 1962 (1906), \# 117, p. 69. 
En otra escena, el rey dirige el ataque contra una fortaleza siria, subido en un carro y con la espada en alto. Se nos muestra, con gran riqueza de detalle, como el ejército tomaba una fortaleza con foso ayudándose de escaleras de asalto y actuando conjuntamente los arqueros egipcios y la infantería shardana ${ }^{116}$.

En una tercera escena es posible ver a Ramses III cargando contra el enemigo sirio a pie y con una lanza en la mano. Ataca una ciudad amurallada construida sobre una colina ${ }^{117}$. Hay una última escena en la que el rey, en su carro de guerra y con el arco tensado, está atacando dos ciudades fortificadas en Siria ${ }^{118}$.

Como en otras campañas, los prisioneros enemigos capturados ${ }^{119}$ son asignados a las explotaciones económicas de los dominios ${ }^{120}$ de Amón-Ra:

"The King himself says to the Crown Prince, Royal Scribe, Chief Commander of the Army, and Royal Son, : "Muster these captives whom the mighty arm of Pharaoh, L.P.H., has carried off. Put th[em in] offices in the House of Amon-Re, King of the Gods, for it was his hand that carried them off.»»121

Otras expediciones, como las realizadas al Pais del Punt ${ }^{122}$, a las minas de Timna y a Serabit el-Jadim ${ }^{123}$ para aprovisionarse de determinados productos escasos o inexistentes en Kemet, no parecen haber tenido contenido bélico, aunque en algunos casos vayan acompañados de tropas.

«J'ai envoyé des échansons et des magistrats au gébel de la turquoise, auprés de (ma) mére ${ }^{t}$ Hathor, souveraine de la turquoise. De l'argent, de l'or, de l'étoffe royale, de l'étoffe mek et des biens $(78,7)$ nombreux ont (litt à moi), un trésor de turquoise véritable ${ }^{950} \mathrm{~m}$ '(en) a été rapporté, dans d'innombrables bourses" apportées devant (moi). (On) n'avait encore jamais vu cela $(78,8)$ depuis les rois (du temps jadis)! ${ }^{95 I_{\gg} 124}$.

En definitiva, las victorias de Ramses III sobre sus enemigos parecen haber conjurado, durante su tiempo, el peligro de invasión en Egipto, preservando la cultura y el orden (la maat) de esta milenaria civilización.

\section{JESÚS TRELLO}

Asociación Española de Egiptología (AEDE) - jtrello@cemad.es

\footnotetext{
116 Ibidem, \# 118, p. 69.

117 Ibidem, \# 119, p. 70.

118 Ibidem, \# 120, p. 70.
}

119 Ver 2.11. The Epigraphic Survey, Later Historical Records of Ramses III, The University of Chicago, Oriental Institute Publications, Chicago 1932, Vol. II, plate 98.

120 Ver 2.11. The Epigraphic Survey, Later Historical Records of Ramses III, The University of Chicago, Oriental Institute Publications, Chicago 1932, Vol. II, plate 99.

121 Ver fig. 2.1. W.F. EDGERTON y J. A. WILSON, Historical Records of Ramses III. The Texts in Medinet Habu. Volumes I and II, Chicago 1936, p. 97. La imagen puede consultarse en EPIGRAPHIC SURVEY, Medinet Habu, Volume II, Later Historical Records of Ramses III, Chicago 1932, plate 91. Ver también J. H. BREASTED, Ancient Records of Egypt, Volume IV, New York 1962 (1906) \# 121, p. 71.

122 Después de la famosa expedición al País del Punt bajo el reinado de Hatshepsut, enviaron expediciones a este lugar los faraones Thutmose III, Amenhotep II, Amenhotep III, Horemheb, Ramses II y Ramses III. Es, por tanto, Ramses III el último faraón en equipar una de estas costosas y complejas expediciones al País del Punt. Ver S. RATIE, La reine Hatchepsout, sources et problemes, Leyden 1979, p. 147.

${ }^{123}$ En el templo de la diosa Hathor en Serabit el-Jadim hay una estela con la fecha, año 23, en la que vemos representado al rey Ramses III haciendo ofrendas a la diosa Hathor, bajo la advocación de «Señora de la Turquesa». Ver J. TRELlO, «La casa de la diosa Hathor en Serabit el-Jadim», Revista de Arqueología n 219, Julio 1999 p. 28-41.

124 Ver P. GRANDET, Le Papyrus Harris I (BM 9999), Volume I, Le Caire 1994, p. 339. 